\title{
Credit default swaps and the UK 2008-09 short sales ban ${ }^{1}$
}

\author{
Jerry Coakley ${ }^{\mathrm{a}}$, Boonlert Jitmaneeroj ${ }^{\mathrm{b}}$ and Andrew Wood ${ }^{\mathrm{c}}$
}

\begin{abstract}
Most studies of the short sales ban of UK financial stocks from September 2008 to January 2009 fail to control for the UK's worst ever banking crisis and the underlying increase in risk. This paper studies the ban's impact on the 13 large financials with credit default swaps (CDS) and 20 smaller stocks without CDS. The results reveal that returns of banned stocks Granger cause CDS returns in the pre- and post-ban periods, but causality runs from CDS to stock returns during the ban period. Underlying risk proxied by the CDS probability of default increased during the ban and the immediate pre- and post-ban periods which highlights an endogeneity problem ignored in some studies. This increased risk provides a plausible rationale for why CDS and related equity bid-ask spreads - which increased during the ban period - failed to fall significantly in the post-ban period. Panel regression results indicate that probability of default was an important economic determinant of stock bid-ask spreads during the ban period. Finally, our results suggest that the ban offered direct price support for the smaller non-CDS stocks during the ban period and indirect support for CDS stocks from their pre-ban to their post-ban levels.
\end{abstract}

Key Words: Bans; short sales; limits to arbitrage; CDS spreads.

JEL classification code: G01, G12, G14, G18.

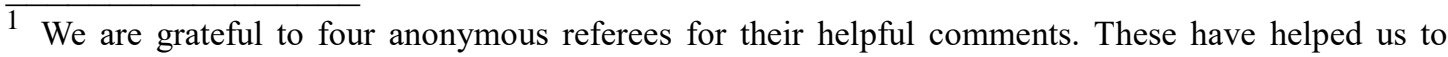
clarify a number of issues and improve the overall exposition of the paper.
}

\footnotetext{
${ }^{a}$ Essex Business School and Essex Finance Centre University of Essex, Wivenhoe Park, Colchester CO4 3SQ, United Kingdom; ${ }^{b}$ School of Business, University of the Thai Chamber of Commerce, Bangkok. ${ }^{c}$ Department of Accounting and Financial Management, University of Portsmouth *Corresponding author: Tel: +44 (0)1206 872455; Fax: +44 (0)1206 873429.

Email: jcoakley@essex.ac.uk.
} 


\section{Introduction}

The UK's worst ever banking and financial crisis commenced in August 2007 when problems arose in the wholesale money markets that had funded considerable parts of all banks' mortgage lending in the run up to the crisis. This led in September 2007 to the collapse of Northern Rock Bank and, subsequently, to problems with other UK former building societies like Alliance and Leicester and Bradford and Bingley that later had to be rescued or taken into public ownership. ${ }^{2}$ The UK banking crisis was part of a broader international banking and financial crisis that adversely affected the US, Ireland and Spain to mention but a few. The collapse of Lehman Brothers in the US in September 2008 proved a particular trigger point in prompting extraordinary responses from governments and regulators alike in implementing their too big to fail (TBTF) policy of protecting strategic banks whose failure could threaten the entire financial system. It provided the backdrop to regulators imposing short sales bans (SSBs) or other constraints such as obligatory disclosure of short positions in September 2008 on the short-selling of financial and other stocks as governments and regulators took defensive action in relation to their banking systems.

The UK ban instigated by the Financial Services Authority (FSA) on September 19, 2008 is of particular interest for several reasons. First, it is unique among major markets in having a duration of some four months as compared with that of 14 days for the US Securities and Exchange Commission (SEC) ban that commenced on the same date. Second, the UK ban covered the creation and increase of net short positions on the London Stock Exchange (LSE) either through the borrowing of stocks or, importantly, using equity-related derivatives. It also required the disclosure of short positions in excess of $0.25 \%$ of the equity capital of the banned stocks. Third, the UK is the only large stock market to have imposed a ban on both covered and naked (open) shorts on financials for an extended period of time. The UK ban

\footnotetext{
${ }^{2}$ See Shin (2009) for a fascinating account of the collapse of Northern Rock.
} 
applied to a heterogeneous group of 33 financials that comprised 13 large cap financials with related equity and credit derivatives and 20 small cap financials without derivatives. Finally, the UK ban coverage did not include related derivatives such as single stock futures (SSF) and credit default swaps (CDS). ${ }^{3}$ Benzennou, ap Gwilym and Williams (2018) argue that SSF can be used to circumvent $\mathrm{SSBs}$ as a short SSF position is a low-cost alternative to short-selling the underlying. However, SSF are less costly and less risky than short selling and have lower margin requirements than spot trades in the underlying. CDS offer insurance on credit risk. Banks and other financials are highly leveraged and so their market risk is largely comprised of credit risk. Thus, CDS enabled investors to take bearish positions on the banned stocks. ${ }^{4}$ Some 13 of the 33 banned financials had related senior and subordinate CDS. Our empirical evidence below shows that the CDS market leads the stock market in terms of price discovery during the ban period.

The major contribution of this paper is that it demonstrates the crucial role CDS returns and the probability of default (PD) associated with the underlying bond as a proxy for underlying risk help us to understand crucial aspects of the SSB. The results underline the central role CDS markets played during the ban period. Causality test results show that CDS returns Granger-cause stock returns during the ban period whilst stock returns lead CDS returns in all other periods. The results indicate that non-CDS stock bid-ask spreads widened during the ban and fell in the immediate post-ban period. These smaller financial results are in line with those in Beber and Pagano (2013). Strikingly, both CDS and related equity bid-ask spreads followed a different pattern, rising markedly during the ban but then remaining high for the immediate post-ban period. Our panel regression results indicate that PD exerted a significantly positive economic impact on equity spreads during the ban period. Finally, our

\footnotetext{
3 The ban included options, futures, depository receipts, contracts for differences, spread bets and dual line stocks.

${ }^{4}$ An investor could take a bearish position in a banned stock during the ban period by buying its CDS. If its default risk increases, then the investor could close her position at a profit by selling the CDS.
} 
cumulative abnormal returns (CARs) results indicate that the SSB offered direct price support for the smaller non-CDS stocks during the ban period and that the ban could be interpreted as supporting large CDS stock CARs between the pre- and post-ban periods.

The second contribution is that our results complement those of the Benzennou et al. (2018) study of SSF that were not included in the UK ban. Unlike our study that focuses on just banned stocks, they investigate all UK SSF data using the 135 contracts in London and 13 in Lisbon from January 2008 until December 2010. Their market wide focus explains the differences between some of their and our results. They find a significant increase in SSF trading activity and narrower SSF spreads. SSF market volatility and market quality were unaffected by the SSB although the latter led to increased turnover. Their results suggest that changes in SSF market activity during the ban period were neutral in relation to the underlying stocks' liquidity, volatility, and volume.

The most comprehensive study on SSB is that by Beber and Pagano (2013) who employ daily data for 16,491 stocks across 30 countries for the January 2008 to June 2009 period. Their main finding was that SSBs worsened liquidity especially for small cap stocks and those without listed options. It also slowed price discovery and failed to support prices for financials with the exception of the USA. Beber and Pagano (2013) acknowledge a potential endogeneity problem in their results which they express as follows: “...if policy makers tend to impose such bans at times when stocks tend to become illiquid for some other reason, the correlation between short-selling bans and market illiquidity documented so far could not be interpreted as a causal relationship" (ibid. p.364). Interestingly, one of the two instruments they use in studying liquidity is the country-level CDS bid-ask spreads for financials. The impact of adding this variable to their regression is to sharply reduce the SSB impact on 
bid-ask spreads. The covered ban coefficient falls from 2.75 to 0.46 for the 12 countries like the UK with partial (financials only) bans. ${ }^{5}$

The final contribution of this paper is that it exploits CDS market information on financials to tackle the endogeneity problem identified by Beber and Pagano (2013). CDS prices are highly informative about both price discovery and underlying default risk. The latter can be captured by the CDS PD that is a forward-looking measure of default risk. The paper traces the trajectory of the latter over a series of sub-periods from August 2006 to April 2010. These include the ban period itself (September 2008-January 2009), the pre- and post-ban periods with disclosure requirements on short positions, the developing Northern Rock and other former building society crisis period, and pre-crisis and post-disclosure years. The general pattern is that the median PD shows a monotonically increasing trajectory from the pre-crisis throughout all the sub-periods up to and including both the ban and immediate post-ban disclosure periods. The PD data show that the default risk of the 13 large cap financials increased during both the ban period and in the immediate post-ban period. This is a novel insight on the UK ban and helps us understand that, while the CDS and related equity bid-ask spreads increased during the ban period, they were non-decreasing thereafter. The implications are twofold. The increase in spreads cannot simply be attributed to the imposition of the ban itself and there is no expectation of a fall in spreads upon lifting the ban.

Our study adds to the literature on SSBs. Only a few studies focus specifically on the UK SSB and virtually all reach a negative verdict on it. Marsh and Payne (2012) study market microstructure effects of the ban. They conclude that the SSB exacerbated problems in valuing UK financials. ${ }^{6}$ The main finding of the Hannson and Fors (2009) study of the UK ban was strong evidence that the bid-ask spreads widened due to the SSB. They also found that the trading volumes and number of trades in the banned stocks fell significantly. Studies

\footnotetext{
5 See columns (5) and (6) in Table II, p.360.

6 Sifat and Mohamad (2015) reach similar conclusions on the market microstructure impact.
} 
that include the UK in larger samples of countries include Beber and Pagano (2013) and Frino, Lecce and Lepone (2011). The latter examine SSBs in 14 countries. Their study stands out because it is one of the very few to conclude that the issue of whether SSBs have a positive net impact remains an open question.

Our paper is also related to a small number of papers that consider the impact of CDS and other derivatives on SSB. One is Ni and Pan (2015) who study the interaction between price discovery in banned stocks and prices of options and CDS during the 2008 US covered ban. They find that stocks with high CDS percentage change have low subsequent returns and so contribute to price discovery. They conclude that derivative prices are more informationally efficient than stock prices during the ban which our Granger causality results support. Battalio and Schultz (2011) and Grundy, Lim, and Verwijmeren (2012) investigate the impact of the US SSB in 2008 on equity option markets and find that bid-ask spreads for the options of banned stocks increased significantly. Our CDS bid-ask spread results exhibit a similar pattern.

The remainder of this paper is organized as follows. Section 2 presents a brief overview of the SSB literature, details of the UK ban and related periods, the banned list and the data sources. Section 3 presents and discusses the empirical results. A final section concludes.

\section{Short sales bans}

\subsection{Literature}

The modern discussion on short selling and the market effects thereof is largely based on Miller (1977). Under heterogeneous expectations he shows that short selling puts pressure on stock prices as the market value incorporates the valuation of all investors, including those with a negative view. The riskier the asset, the larger the effect as the dispersion of opinions is 
wider. In the presence of short sales restrictions, the price will reflect the views of optimistic investors. Chang et al. (2007) and Jones (2012) provide empirical results confirming the outcome of Miller (1977) when short selling is difficult or prohibited.

Hong et al. (2012) demonstrate that short arbitrage in stock markets can amplify the impact of economic shocks. Since the ability of speculators to hold on to short positions depends on stock prices, shorts are often increased following bad news about a stock and vice versa for good news. The upshot is that the prices of highly shorted stocks overreact to economic shocks and they establish evidence consistent with this destabilizing mechanism. They find that the price of a highly-shorted stock is more sensitive to (earnings) news than a stock with little short interest and that the change in short interest in response to news is more sensitive to surprises for highly shorted stocks. They confirm that these effects are more pronounced for stocks which are easier to short (e.g. NASDAQ rather than NYSE stocks) and these effects have become more pronounced over time for small stocks with the rise of hedge funds.

Several studies of the recent bans have already appeared. Hansson and Fors (2009) study the UK short sale ban period using intraday data for the equity market only. They find no evidence of effects of the ban on abnormal returns and volatilities. They attribute this to the extreme levels of noise during the financial crisis. However, they do establish that the bid-ask spreads in the affected stocks widened during the ban and that the trading activity in the banned stocks decreased.

Boehmer et al. (2013) study the US Securities and Exchange Commission (SEC) ban on most short sales in more than 800 financial stocks. This differed from the UK ban in being less intensive, covering a shorter period but also a much wider range of financial stocks. They match banned stocks to a control group of non-banned stocks to identify the ban effects. They find that shorting activity fell by $77 \%$ and that the stocks subject to the ban exhibited 
increases in spreads, price impacts, and intraday volatility. While the prices of stocks subject to the ban increased sharply, this may be because of the Troubled Asset Relief Program (TARP) and other initiatives announced the same day rather than to the ban itself. The conclusion is that they are sceptical about any beneficial effects of the ban and instead stress its deleterious effects on market quality as measured by increased spreads.

The UK short sale ban is also included in two more comprehensive studies. Beber and Pagano (2013) exploit the variation in short-sales regimes across 30 economies in terms of both their intensity and duration to identify their effects using panel data techniques. They find that the bans were detrimental for liquidity especially for small cap, high volatility stocks with no listed options. They further establish that bans slowed down price discovery and failed to support stock prices, with the possible exception of US financial stocks.

The UK is also included in the Frino et al. (2011) study of the impact of 2008 bans on market quality. Their findings indicate that SSBs lead to artificially inflated prices as indicated by positive abnormal returns in line with Miller's (1977) overvaluation theory. They are one of the few to interpret this as bans being effective in temporarily stabilizing prices in struggling financial stocks. They recognize that SSBs involve a deterioration in market quality proxied by wider bid-ask spreads, increased price volatility and reduced trading activity.

\subsection{UK short sales ban periods}

The focus of this paper is on the UK short sales ban. However, the ban itself needs to be placed within the much broader scope of regulatory intervention during the periods both before and after the ban by the FSA (the regulatory authority). As well as the actual short sales ban period, the FSA implemented two separate requirements for disclosure of net short positions in financial sector companies that are largely ignored in extant studies. One can 
distinguish between six separate phases around the FSA intervention on net short positions in the UK in 2008 and 2009.

i) $9 / 8 / 06-8 / 8 / 07$. The Pre-crisis year includes the year from August 2006 preceding the financial crisis.

ii) $\quad 9 / 8 / 07-19 / 6 / 08$. The Pre-disclosure crisis period is the one from the Northern Rock crisis up to the first short sales disclosure. This period includes the Bear Stern collapse on 16/03/2008.

iii) $\quad 20 / 6 / 08-18 / 9 / 08$. Disclosure \#1 is the period requiring disclosure of net short positions in financial sector companies about to make a rights issue. The tail end of this period includes the Lehman Brothers collapse on 15/09/2008.

iv) $19 / 9 / 08-16 / 1 / 09$. This is the SSB period proper. A government arranged rescue/ takeover of HBOS by Lloyds was announced on 16/09/2008.

v) $17 / 1 / 09-17 / 5 / 09$. Disclosure \#2 is the period involving disclosure of net short positions in financial sector companies of $0.25 \%$ and above, incremental increases of 0.01 in these positions, and a decrease below the $0.25 \%$ threshold in these positions.

vi) $18 / 5 / 09-17 / 5 / 10$. The Post-disclosure period is the year following the lifting of Disclosure \#2.

It is important to be aware of these separate periods. Virtually all existing UK studies treat the immediate pre- and post-ban periods as normal periods when in fact they include specific disclosure restrictions. Moreover, they include major shocks such as the Lehman Brothers collapse just prior to the SSB and the government arranged rescue/takeover of HBOS by Lloyds on the last day of the SSB. Whilst the former was a bad shock, the Lloyds takeover was a good one for the banking sector to the extent that it signaled that the UK 
government was prepared to do what was needed to secure the stability of the UK banking system.

\subsection{Banned list}

The UK ban targeted all net short (both covered and naked) positions in UK financial sector companies. These included not only the UK's biggest banks and insurers but also smaller banks, insurers and fund managers and hedge funds. The ban covered an initial list of 29 stocks over the period from September 18, 2008 to January 16, 2009. Seven companies were added to the banned list in the first two weeks of the ban and six companies on the list were delisted early in the ban period due to takeovers and related reasons. ${ }^{7}$ This yields a total of some 33 banned companies which are listed in Table 1.

[Table 1 around here]

In conjunction with the short sales ban, the FSA required daily disclosure of all net short positions in excess of $0.25 \%$ of the ordinary share capital in the banned stocks. The disclosure regime was set to end on June 30, 2009. It was relaxed from daily disclosure to cover only changes in excess of 10 basis points (bp) starting from a $25 \mathrm{bp}$ net short position or reductions below a $25 \mathrm{bp}$ net short position in the post-ban period.

CDS contracts are traded over the counter for large banks and insurance companies. We were able to obtain daily CDS information for some 13 out of the 33 banned list companies from CMA-Datastream. These companies and their sample spans are listed in Table 2.

[Table 2 around here]

Some 8 of the 13 companies are the major UK banks, 4 are major insurers and the final one

\footnotetext{
7 These included Alliance \& Leicester plc and Bradford \& Bingley plc (both taken over by Banco Santander), HBOS plc (taken over by Lloyds TSB), Lloyds TSB Group plc (became Lloyds Banking Group plc), London Scottish Bank plc (went into administration on November 20, 2008) and Highway Insurance group (takeover by Liverpool Victoria announced October 17, 2008).
} 
(Old Mutual) is a hedge fund. The sample spans for the companies extend from late 2006 up to the middle of 2010 .

\section{Empirical results}

This paper highlights the hitherto neglected role of CDS which fell outside the remit of the UK SSB. In principle, investors could have used CDS to take bearish positions in the underlying financials during the ban since, apart from SSF, other types of bearish behaviour were not permitted. However, it is possible that this is just a curiosity and that investors shunned the CDS market during the ban period. Thus, our empirical analysis starts by examining the role of CDS in price discovery before, during and after the ban period. In the subsequent analysis, we use daily data on 5-year euro-denominated CDS with modified-modified restructuring. ${ }^{8}$

\subsection{Price discovery}

One aspect of the $2008 \mathrm{SSBs}$ that has received relatively little attention is price discovery. One reason for this is lack of appropriate data. The availability of CDS data enables us to test for lead and lag relationships between the banned CDS stock returns and their CDS returns. Log stock and CDS returns are employed in the Granger-Causality (GC) specification. ${ }^{9}$ The GC test results are based on the Moment Model Selection Akaike Criterion (MAIC) in a panel VAR (pVAR) specification. Relevant dummy variables for confounding events are introduced

\footnotetext{
${ }^{8}$ In response to the perception of some market participants (particularly in Europe) that the modified restructuring had been too severe in its limitation of deliverable obligations, a further modification of the modified restructuring clause was introduced in 2003. Under the modified-modified restructuring, the remaining maturity of deliverable assets must be shorter than 60 months for restructured obligations and 30 months for all other obligations (Packer and Zhu, 2005).

${ }^{9}$ As demonstrated by Hilscher et al. (2015), the credit protection return is equal to the percentage change in CDS prices adjusted by the ratio of two annuity factors. As the adjusted ratio will always be close to one, the credit protection return is thus well approximated by the percentage change in CDS prices. In this respect, we follow a number of recent studies in leading international journals that investigate the effects of CDS markets on information transmission by using the first log-difference of CDS mid prices as the proxy for CDS returns (e.g., Batta et al., 2016; Friewald et al., 2014; Oehmke and Zawadowski, 2017; Qiu and Yu, 2012).
} 
for each sub-period as well as the whole sample period. ${ }^{10}$ Since the CDS market is an OTC market, one would normally expect the more liquid equity market to lead the CDS market. However, there is some evidence that CDS markets may lead equity markets in bearish circumstances such as crisis periods. Limits to arbitrage kick in during crisis periods - it becomes very expensive or impossible to borrow stock for covered short positions. CDS allowed bearish investors one legitimate means of circumventing the SSB since shorting the underlying equity shares was banned. This leads to the following hypotheses:

H1A: Stock returns Granger-cause CDS returns.

H1B: CDS returns Granger-cause stock returns.

The results of the GC tests with a range of relevant exogenous dummy variables are reported in Table $3 .^{11}$

[Table 3 around here]

The results for the full sample period indicate that stock returns Granger-cause CDS returns and this is significant at the $1 \%$ level. This result is as expected but there may well be variation during sub-sample periods. The most interesting finding is that for the ban period itself. Here the results reveal that CDS returns Granger cause stock returns and this finding is significant at the $1 \%$ significance level. This supports H1B. None of the dummy variables is significant for this period. This confirms the central role of CDS as the main price discovery mechanism during the ban period. This important result is consistent with investors actively using the CDS market during the ban period and this serves to justify the paper's novel focus on CDS. This finding rejects H1A and is consistent with investors using CDS to take bearish positions during the ban period.

However, stock returns lead CDS returns in all other sub-periods. These findings

\footnotetext{
10 The GC results from estimating a base-line model without exogenous variables are qualitatively similar.

11 Some studies (e.g., Pan and Singleton, 2008) have identified an idiosyncratic component in the short-term CDS maturity, possibly related with liquidity issues and short-term distress. We therefore extend our analysis to the 1-year CDS maturity whose results are very similar to those of the 5-year CDS maturity in Table 3 . The estimation results of the 1 -year CDS maturity are available on request.
} 
support H1A. Note that the Bear Stern dummy is significant for both CDS and stocks (with opposite signs) during the pre-disclosure period. The Lehman dummy for the pre-ban (Disclosure \#1) period is also significant (with absolutely larger coefficients than the Bear Stern dummy) for both CDS and stocks. The absolute magnitude of the Lehman coefficient for CDS $(0.0712)$ is also larger than that for stocks $(-0.0466)$ for the latter period.

Recent findings in the related literature on credit risk discovery are mixed. Our finding on the price discovery role of CDS during the ban period is consistent with that of researchers who find that the CDS market plays an important role in some instances. For instance, Chau, Han and Shi (2018) find the contribution of the CDS market to credit risk discovery in the US market significantly improves during the sub-prime crisis. Similarly, Kryzanowski, Perrakis, and Zhong (2017) find that the CDS market's relative contribution to price discovery increases significantly for negative (earnings) shocks, especially with high firm-specific uncertainty. UK financials during the SSB are a good example of the latter.

\subsection{Bid-ask spread results}

\subsubsection{Stock spreads}

Most of the studies of the 2008 UK SSB have focused on stock bid-ask spreads and related measures of equity liquidity for all the banned financials. The banned stocks range from leading UK-based international banks (like Barclays and HSBC) to a diverse range of quite small financials and so heterogeneity in results is to be expected. This duality is captured by CDS since only the larger financials have OTC traded CDS. Moreover, since bearish derivative positions and short sales are approximate substitutes, CDS play an important role as a means of partially circumventing the ban for the 13 stocks with CDS. Ceteris paribus, one would expect moderate changes in the spreads of the 13 CDS stocks. This is because, while CDS can be used to take bearish short positions in these stocks, they cannot be used to create 
outright synthetic short positions in these stocks. Moreover, if the overall risk of the CDS stocks increases during the ban period, then their spreads would necessarily increase also. By contrast, we expect the spreads of the much smaller non-CDS stocks to increase sharply, partly due to the absence of CDS and partly due to the fact that smaller stocks generally become much more illiquid in crisis situations. Finally, if the SSB is the main driver of bid-ask spread increases, then spreads should fall in the immediate post-ban period.

This leads to the following two hypotheses that are formulated in terms of medians as the spreads of financials in difficulties distort the mean measures.

H2A: The median bid-ask spread for CDS stocks increases by less than that for non-CDS stocks during the ban period.

H2B: The median bid-ask spread for stocks falls after the ban period.

Table 4 presents the bid-ask spread for all the banned stocks. The spread is defined as the difference between the bid and ask prices relative to their average.

[Table 4 around here]

Panel A presents summary statistics of the bid-ask spreads for firms with CDS for the six sub-periods around the ban and for the whole sample period. The focus of the analysis is on sub-periods immediately surrounding the ban period. The table indicates that the median spreads of CDS financials were approximately the same in the pre-disclosure $(0.08 \%)$ and Disclosure\#1 (pre-ban) $(0.10 \%)$ periods. They then increased to $0.18 \%{ }^{12}$ during the ban period. Table 4, Panel B presents summary statistics of the stock bid-ask spreads for the 20 firms without CDS. This table shows results that are broadly similar in direction to those in Panel A but whose increases during the ban period are much more extreme. The smaller non-CDS firms' stock spreads are always higher than those of the CDS firms. They trebled from $0.29 \%$ to $0.91 \%$ during the ban period and this is significantly larger than the CDS stock

\footnotetext{
12 This reflects the exclusion of Alliance and Leicester whose board accepted a takeover by Santander in
} mid-July 2008 
increase. So H2A cannot be rejected.

The CDS spreads fall back slightly to $0.16 \%$ in post-ban period. However, the $\mathrm{Chi}^{2}(1)$ result fails to reject $\mathrm{H} 2 \mathrm{~B}$ for the ban versus the post-ban period at the $5 \%$ level or better. This latter finding is novel and rejects $\mathrm{H} 2 \mathrm{~B}$. This is consistent with the later results that default risk for large financials remained at very high levels until the end of the Disclosure\#2 period. The smaller non-CDS spreads fell significantly in this period. So H2B is not rejected. This finding is also consistent with that of Beber and Pagano (2013) on smaller stocks during the ban.

Another way of looking at spreads is the CDS versus the non-CDS differentials. The median differential is just $19 \mathrm{bp}$ in in the immediate pre-ban period but it jumps by a factor of 4 to some $73 \mathrm{bp}$ during the ban period before falling to $40 \mathrm{bp}$ in the immediate post-ban period. Extant studies that rely on overall (CDS and non-CDS) median changes are misleading since they are driven by the very volatile spreads of these smaller, riskier firms.

\subsubsection{CDS spreads}

Extant studies of SSB bid-ask spreads are beset by an endogeneity issue. This refers to the crucial question of whether the ban itself by reducing market liquidity caused spreads to increase or whether other factors such as default risk may also have impacted on spreads as Beber and Pagano (2013) acknowledge. Our paper exploits the fact that 13 banned financials had quoted senior and subordinate CDS while the remaining 20 mainly smaller firms did not. Since the 2007-2009 crisis was primarily a funding crisis, the role of CDS as a measure of default risk is key to understanding it. Since bearish positions on banned financials could be taken by buying their CDS, this increased demand would trigger an increase in CDS bid-ask spreads during the ban period.

Grundy et al. (2012) in their study of whether options undo US short sales restrictions found a significant increase in option bid-ask spreads for banned relative to unbanned stocks 
due to + increased demand. In this spirit, we propose the following hypotheses:

H3A: The median spreads for senior CDS spreads increase during the ban period.

H3B: The median spreads for senior CDS spreads decrease after the ban period.

H3C: The median subordinate CDS spreads increase during the ban period.

H3D: The median subordinate CDS spreads decrease after the ban period.

Table 5 presents summary statistics of bid-ask spreads for senior CDS and subordinate

CDS. We report results for both the absolute spread and relative spread where the latter is defined as the absolute spread divided by the average of bid and ask prices.

[Table 5 around here]

Panel A indicates that the ban period saw a rise in the median senior CDS relative bid-ask spread, from $7.2 \%$ in the Disclosure\#1 period to $9.0 \%$ in the ban period, before easing to $8.3 \%$ in the Disclosure\#2 period. The increased spread during the ban period is consistent with increased demand for CDS for bearish positions in the underlying. The actual spread of senior CDS levels doubled from $6.0 \mathrm{bp}$ to $12.0 \mathrm{bp}$ from Disclosure\#1 to the ban period. This increase is significant at the $1 \%$ level and supports $\mathrm{H} 3 \mathrm{~A}$. The spreads remained unchanged at 12.0bp during the Disclosure\#2 period and this rejects H3B. These results are consistent with the CDS stock spread results.

The Panel B results are for subordinate CDS spreads which are more sensitive to default risk. The results indicate changes in similar directions and but with much larger magnitudes up to and during the ban period. Interestingly, the ban subordinate spread levels of $20.0 \mathrm{bp}$ are double their Disclosure\#1 levels and this increase is significant at the $1 \%$ level, with a $\mathrm{Chi}^{2}(1)$ of 459.19 . This supports H3C. Note that this ban period 20.0bp spread is almost double that of $12.0 \mathrm{bp}$ for senior CDS. Strikingly, the subordinate CDS spreads exhibit a significant increase to $30.0 \mathrm{bp}$ during the Disclosure\#2 period. This increase differs from the corresponding stock and senior CDS spreads that remained constant between these periods. 
These subordinate spread increases immediately after the ban period are statistically significant and they reject Hypothesis H3D. They are consistent with an underlying increase in default risk over the course of the ban and its immediate surrounding periods. This is a novel finding in the context of the UK SSB.

\subsubsection{Liquidity transmission between CDS contracts and stocks}

Earlier research finds that the liquidity of corporate CDS is relatively scarce (e.g., Bongaerts et al., 2011; Bühler and Trapp, 2009; Nashikkar et al., 2011; Tang and Yan, 2008). Illiquidity is then thought of as the cost of trade due to market frictions, of which there are several dimensions. It could be increased bid-ask spread or decreased depth due to asymmetric information in the market. Although the causal link between CDS and stock returns has been studied extensively in the literature, relatively little is known about liquidity spillover between CDS and stock markets. In this respect, we use the pVAR model and Granger causality test to provide additional insights into the liquidity relationship between CDS contracts and stocks.

Using the bid-ask spreads as proxies for liquidity, the estimation results are shown in Table 6.

[Table 6 around here]

Over the full sample period, CDS contracts play a leading role in liquidity spillover. This finding is in line with previous studies of liquidity transmission between CDS and stock markets (e.g., Haas and Reynolds, 2017; Jacoby et al., 2009; Marra, 2017; Tang and Yan, 2008). The unidirectional causal relationship from CDS contracts to stocks also applies in all sub-periods except for bi-directional relations in the pre-crisis and Disclosure\#2 sub-periods and no causal link in the ban period.

\subsection{Quantifying default risk}




\subsubsection{CDS default risk}

The 2007-09 financial crisis was primarily a money market funding crisis. Banks, insurance companies, and other financials had large outstanding sums of short term debt that were routinely rolled over at maturity in normal times. At the onset of the crisis, this source of short-term funds largely dried up leaving banks and others with severe liquidity problems. CDS data provide a unique measure of default risk to capture these short-term funding problems. In particular, the probability of default (PD) is an estimate of the likelihood that a default event related to a financial firm's counterparty will occur over a particular horizon, usually one year. They can be employed to view the evolution of expected default risk prior to, during, and after the SSB. Of particular interest is whether default risk increased during the ban period since most SSB studies with the exception of Beber and Pagano (2013) implicitly assume that it remains constant.

H4A: PD remains constant from the pre-ban to the ban period.

H4B: PD remains constant from the ban to the post-ban period.

Using CDS PD data we can explicitly test these hypotheses. In this study, we adopt Norden and Weber's (2010) approach to compute the market-implied PD under the assumption of risk neutrality and $100 \%$ constant loss given default (LGD) on subordinate CDS. By using different seniorities of CDS contracts, we calculate PD from a system of equations (1) $\frac{\mathrm{LGD}^{\mathrm{SUB}}}{\mathrm{LGD}^{\mathrm{SEN}}}=\frac{\mathrm{CDS}^{\mathrm{SUB}}}{\mathrm{CDS}^{\mathrm{SEN}}}$ with $\mathrm{LGD}^{\mathrm{SUB}}=100 \%$ and $(2) \mathrm{PD}=\frac{\mathrm{CDS}^{\mathrm{SUB}}-\mathrm{CDS}^{\mathrm{SEN}}}{\mathrm{LGD}^{\mathrm{SUB}}-\mathrm{LGD}^{\mathrm{SEN}}}$ where LGD $^{\text {SUB }}$ is the market-implied loss given default of subordinate CDS, LGD ${ }^{\text {SEN }}$ is the market-implied loss given default of senior CDS, $\operatorname{CDS}^{\mathrm{SUB}}$ is the credit default swap premium of subordinate CDS, and $\operatorname{CDS}^{\mathrm{SEN}}$ is the credit default swap premium of senior CDS. ${ }^{13}$

\footnotetext{
${ }^{13}$ We note that risk proxies derived from derivatives - e.g., implied volatility or risk neutral skewness from options - are generally derived under the risk neutral measure or assumption of risk neutrality. However, our PD measure disregards both risk premia arising due to agents being risk-averse and illiquidity premia that both are known to be typically non-trivial and to rise during crises (e.g., Amato, 2005; Corò et al., 2013). Ignoring this may overstate default probability estimates, particularly during the crisis period.
} 
Table 7 presents data on PD for the 13 companies with CDS.

[Table 7 around here]

The median PD gives an indication of the default risk of financials over the course of the sample period. The banks that got into financial difficulties during the crisis period (Bradford and Bingley, HBOS, Lloyds, and RBS) suffered particularly sharp increases of well in excess of 10-fold each. For instance, Lloyds' median PD increased almost 18 -fold from $0.08 \%$ pre-crisis to $1.43 \%$ during the ban period. Across all firms, the median PD increased 17 -fold from $0.14 \%$ to $2.40 \%$ from the pre-crisis to the ban period.

The general pattern is that the median PD shows a monotonically increasing trajectory from the pre-crisis throughout all the sub-periods up to and including the post-ban (Disclosure\#2) period. It registered a highly significant increase from $1.70 \%$ to $2.40 \%$ between the pre-ban and ban periods and it almost doubled to 4.18 during the post-ban period. Both increases are significant at better than the $1 \%$ significance level. These data resoundingly reject $\mathrm{H} 4 \mathrm{~A}$ and $\mathrm{H} 4 \mathrm{~B}$ that default risk remained constant during and after the ban period. Looking at individual banks, each one with a CDS saw a significant increase in PD in Disclousure\#2 following the lifting of the ban with the single exception of RBS which was effectively taken into government ownership. Assuming that the FSA had access to these data confirming Britain's worst banking crisis in living memory before the SSB, it would not have hesitated in imposing the ban.

The upward trajectory of default risk throughout all the sub-periods excluding the post-disclosure is interesting given several confounding events which extant studies ignore. One was the announced takeovers of Alliance and Leicester and Bradford and Bingley by Banco Santander in September 2008. The other was the Labour government's rescue package announced in November 2008 which had three components. One was a new liquidity facility for all financials. The second was a fund for government purchase of shares through the Bank 
Recapitalisation Fund. The two major beneficiaries of the latter were Lloyds and RBS. The final one was the government temporarily underwrote any eligible lending between British banks up to a limit of $£ 250 \mathrm{bn}$.

In this sense, the SSB perhaps temporarily slowed down the rate of increase in default risk as proxied by the median PD but still it increased sharply in the immediate post-ban period. What these results indicate is that the crisis as proxied by the median PD deepened from the pre-ban period up to and including the ban and post-ban periods and that these were very far from normal periods in terms of risk. Thus, studies that treat the pre- and post-ban periods on a ceteris paribus basis ignore this crucial feature of rising default risk as the crisis deepened. They further suggest that increased underlying default risk contributed significantly to widening equity spreads during the ban period.

\subsubsection{Impact of PD on spreads}

The univariate results presented so far suggest that increased underlying default risk is a potentially important factor in explaining the worsening liquidity situation in the equity market during the SSB and its immediate aftermath. We now employ multivariate analysis to investigate this. We regress the stock bid-ask spread on a Ban period dummy, two (pre- and post-SSB) disclosure dummies, and interactive PD dummies to compare bid-ask spreads across the sub-periods. We employ a log-log specification to render the impacts of a change in each independent variable comparable in relative size terms. This leads to the following hypotheses:

H5A: Stock bid-ask spreads are affected by ban and surrounding period disclosure events.

H5B: Stock bid-ask spreads are also affected by underlying risk factors. 
The events are captured by time dummies and the risk factors are captured by interactive dummies involving the probability of default (PD) during particular periods.

The regression results are presented in Table 8 .

[Table 8 around here]

The results for Model 1 focus on time dummies only. The coefficients on all three period dummies are positive and significant statistically at the $1 \%$ level. They confirm that the economic impacts of the ban period dummy are higher than those during both Disclosure \#1 and \#2 periods. These results support H5A. They are also consistent with the summary statistics for bid-ask spreads reported in Table 4.

Model 2 in Table 8 adds PD interacted with the three time-period dummies to the Model 1 dummies. The coefficients on PD interacted with all periods are all statistically and economically significant and these results support H5B. The results indicate that the impact of the Ban time dummy decreases from 0.798 in Model 1 to 0.577 in Model 2. The difference is exactly accounted for by the PD*Ban dummy coefficient of 0.220 in Model 2. In other words, underlying risk in Model 2 accounts for almost 30\% of the impact of the Ban effect in Model 1.

\subsection{Price support}

A primary objective of the SSB was to support prices from aggressive short selling during periods of extreme uncertainty resulting from the crisis. Table 9 reports summary statistics of daily returns for CDS and non-CDS stocks. The stock return is defined as the first log-difference of the closing prices. It is evident that, in terms of risk and return, non-CDS stocks outperform CDS stocks during the pre- and post-ban disclosure periods. It is extremely difficult to test the effectiveness of the SSB in achieving this objective given the absence of a counter factual or comparable benchmark. Nonetheless, to examine price support, we 
compute cumulative abnormal returns (CARs) for the banned stocks for the ban period itself and the pre- and post-ban disclosure periods.

[Figure 1 around here]

Figure 1 presents median CARs for the banned stocks for the ban period itself and the pre- and post-ban disclosure periods. The two diagrams show contrasting patterns for the larger stocks with CDS and the smaller non-CDS stocks. The CDS stock CARs are approximately stable in the pre-ban period, experience high volatility and a sharp fall during the ban period. This was followed by an almost immediate recovery and a generally improved performance in the post-ban period, similar to that for the USA reported in Beber and Pagano (2013). ${ }^{14}$ By contrast, the smaller non-CDS stocks exhibit an upward trend in CARs prior to and during the ban period followed by a sharp drop after the ban was lifted and then a gradual recovery.

This leads to the following hypotheses:

H6A: CDS stock CARs fall during the ban period and increase in the post-ban period.

H6B: Non-CDS stock CARs rise during the ban period and decrease in the post-ban period.

H6C: All CARs increase between the pre- and the post-ban periods.

These hypotheses are tested in Table 10.

[Table 10 around here]

The results of tests for equality of medians indicate that CDS stock CARs fell sharply to -13.27 during the ban period before recovering to 6.14 in the post-ban period. ${ }^{15}$ Both of these changes are significant at the $1 \%$ level and these changes support H6A. It is impossible to know what would have happened in the absence of the SSB but one possibility that cannot be excluded is that the SSB prevented an even sharper fall in CAR for the CDS stocks at the

\footnotetext{
14 Note that their US post-ban results cover a period of only 14 days.

15 The focus is on the medians as these are robust to outliers.
} 
epicentre of the UK's worst ever banking crisis. By contrast, equality of median results show that non-CDS stock CARs rose sharply to 9.45 before stabilising around this level in the post-ban period. These support the increase part of $\mathrm{H6B}$ but reject the decrease in the post-ban period. These results could be interpreted as evidence of the SSB offering price support for the smaller non-CDS financial firms during the ban period and of the fact that most of these firms were not directly implicated in the ongoing banking crisis.

One problem interpreting our results is that disclosure requirements during the immediate post-ban period makes it difficult to distinguish between the separate effects of the lifting of the ban and the imposition of disclosures. However, some evidence can be gleaned by equality of median tests for the pre- and post-ban periods since the disclosure requirement was broadly similar in both periods. Both CDS and non-CDS CARs exhibit significant increases from the pre-ban period levels relative to their post-ban period levels. Since the ban could be seen as a shock in between these two periods, the CAR results provide indirect evidence of a significantly positive price support impact from the ban and support H6C.

The CAR results are all the more interesting given that immediate post-ban period was one of extreme uncertainty. It coincided with the finalising of the merger between Lloyds and HBOS but, more importantly, with concerns about HBOS write-downs. This led to calls for the nationalisation of Lloyds by converting the government's preference shares to equity and fears that this could lead to a domino effect which could potentially bring down Barclays. ${ }^{16,17}$ The first week following the lifting of the ban, hedge funds were reported to be shorting bank stocks, particularly Barclays, albeit at lower levels than prior to the ban. ${ }^{18}$ This period of extreme uncertainty was short lived, with both Lloyds and Barclays recovering strongly following the publication of an open letter by both the chairman and chief executive of

\footnotetext{
16 Lloyds opened on the 19 January at 52.43, falling to a low of 29.76 before closing at 32.24 . The following day saw a low of 16.76 (Bloomberg).

17 "Fears spark uneasy start to Lloyds Banking Group", Financial Times (20/1/09)

18 “Paulson reaps $£ 270 \mathrm{~m}$ 'shorting’ RBS”, Financial Times (27/1/09)
} 
Barclays announcing stronger than expected profits which allayed the fear that there was a need to raise additional capital.

\section{Conclusions}

This paper investigates the UK short sales ban on 33 financial stocks from September 2008 to January 2009. Credit default swaps (CDS) on 13 large stocks were not among the list of derivative instruments covered by the ban. CDS are relevant since they furbish the opportunity for investors to take bearish positions in the related banned stocks but also their probability of default measure provide a forward-looking indication of default risk. Moreover, they played a critical price discovery role during the ban period. This is confirmed by our econometric results showing that CDS returns Granger cause stock returns during the ban period whilst stock returns lead CDS returns in all other periods.

Our results indicate the smaller non-CDS stock bid-ask spreads widened during the ban and then narrowed afterwards, both CDS and related equity bid-ask spreads either remained constant or increased in the immediate post-ban period. More interestingly, the probability of default (PD) increased monotonically from the pre-ban period to the end of the post-ban period These findings suggest that extant studies of the UK SSB that ignore the non-decreasing CDS bid-ask spread pattern and the increasing PD during and after the ban may need to be qualified. Our panel regression results indicate that the two most important determinants of bid-ask spreads were time-period dummies and PD. They show that the latter exerted a significantly positive economic impact on spreads in the pre-ban and ban periods. Finally, our CAR results indicate that the SSB offered direct price support for the smaller non-CDS stocks during the ban period and that it could be interpreted as supporting large CDS stock CARs between the pre- and post-ban periods.

Overall our results indicate that the impact of the UK SSB is a more nuanced process 
than most recent studies allow. The ban and related disclosure measures were imposed in the midst of the UK's worst ever banking crisis and this needs to be taken into account. Accordingly, the existing consensus that the UK SSB simply had a range of negative effects needs to be revised. While CDS stock bid-ask spreads increased during the ban period, they then either rose or failed to fall significantly after the lifting of the ban due to the underlying increase in default risk. The novel explanation advanced in this paper is the default probability of banned CDS stock increased before the ban, during it, and in the immediate post-ban period.

While our study provides important insights into the causal linkage between CDS and stock during the UK 2008-09 short sales ban, its limitations suggest future avenues for empirical research. ${ }^{19}$ The dynamic causality relationships across percentiles through a rolling window scheme could provide a clearer picture of the possible dynamic linkages at different parts of the distributions of CDS and stock returns. Rolling analysis allows for the detection of changes in the direction of causality over time (e.g., Delis and Mylonidis, 2011). Moreover, our PD measure inferred from the prices of subordinate and senior CDS disregards both risk premia arising due to agents being risk-averse and illiquidity premia. Ignoring this may overstate default probability estimates, particularly during the crisis period. Future research should employ other PD measures, for example, Moody's KMV expected default frequencies (EDFs) (e.g., Díaz et al., 2013).

\footnotetext{
19 We are grateful to two anonymous referees for these suggestions
} 


\section{References}

Amato, J.D. (2005). Risk aversion and risk premia in the CDS market. BIS Quarterly Review, December.

Batta, G., Qiu, J., \& Yu, F. (2016). Credit derivatives and analyst behavior. Accounting Review, 91(5), 1315-1343.

Battalio, R., \& Schultz, P. (2011). Regulatory uncertainty and market liquidity: the 2008 short sale ban's impact on equity option markets. Journal of Finance, 66(6), 2013-2053.

Beber, A., \& Pagano, M. (2013). Short selling bans and market liquidity around the world: Evidence from the 2007-09 crisis. Journal of Finance, 68(1), 343-381.

Benzennou, B., ap Gwilym, O., \& Williams, G. (2018). Are single stock futures used as an alternative during a short-selling ban? Journal of Futures Markets, 38(1), 66-82.

Boehmer, E., Jones, C.M., \& Zhang, X. (2013). Shackling short sellers: The 2008 shorting ban. Review of Financial Studies, 26(6), 1363-1400.

Bongaerts, D., Jong, F.D., \& Driessen, J. (2011). Derivative pricing with liquidity risk: Theory and evidence from the credit default swap market. Journal of Finance, 66(1), $203-240$.

Bühler, W., \& Trapp, M. (2009). Time-varying credit risk and liquidity premia in bond and CDS markets. Working Paper.

Chang, E.C., Cheng, J.W., \& Yu, Y. (2007). Short-sales constraints and price discovery: Evidence from the Hong Kong market. Journal of Finance, 62(5), 2097-2122.

Chau, F., Han, C., \& Shi, S. (2018). Dynamics and determinants of credit risk discovery: Evidence from CDS and stock markets, International Review of Financial Analysis 55, 156-169.

Corò, F., Dufour, A., \& Varotto, S. (2013). Credit and liquidity components of corporate CDS spreads. Journal of Banking and Finance, 37(12), 5511-5525. 
Díaz, A., Groba, J., \& Serrano, P. (2013). What drives corporate default risk premia? Evidence from the CDS market. Journal of International Money and Finance, 37, 529-563.

Friewald, N., Wagner, C., \& Zechner, J. (2014). The cross-section of credit risk premia and equity returns. Journal of Finance, 69(6), 2419-2469.

Frino, A., Lecce, S., \& Lepone, A. (2011). Short sales constraints and market quality: Evidence from the 2008 short sales bans. International Review of Financial Analysis, 20(4), 225-236.

Grundy, B.D., Lim, B., \& Verwijmeren, P. (2012). Do option markets undo restrictions on short sales? Evidence from the 2008 short-sale ban. Journal of Financial Economics, 106(2), 331-348.

Hansson, F. \& Fors, E.R. (2009). Get Shorty? Market impact of the 2008-09 U.K. Short selling ban. Working Papers in Economics No. 365, University of Gothenburg.

Haas, M., \& Reynolds, J. (2017). Illiquidity Contagion and Information Spillover from CDS to Equity Markets. SSRN: https://ssrn.com/abstract=2606164.

Hilscher, J., Pollet, J.M., \& Wilson, M. (2015). Are Credit Default Swaps a Sideshow? Evidence That Information Flows from Equity to CDS Markets. Journal of Financial and Quantitative Analysis, 50(3), 543-567.

Hong, H., Kubik, J.D., \& Fishman, T. (2012). Do arbitrageurs amplify economic shocks? Journal of Financial Economics, 103(2), 454-470.

Jacoby, G., Jiang, G. J., \& Theocharides, G. (2009). Cross-market liquidity shocks: Evidence from the CDS, corporate bond, and equity markets. Working Paper.

Jones, C.M. (2012). Shorting Restrictions: Revisiting the 1930's. The Financial Review, 47(1), 1-35. 
Kryzanowski, L., Perrakis, S., \& Zhong, R., (2017). Price discovery in equity and CDS markets, Journal of Financial Markets 35, 21-46.

Marra, M. (2016). Explaining co-movements between equity and CDS bid-ask spreads. Review of Quantitative Finance and Accounting, 49(3), 811-853.

Marsh, I.W., \& Payne, R. (2012). Banning short sales and market quality: The UK's experience. Journal of Banking and Finance, 36(7), 1975-1986.

Miller, E.M. (1977). Risk, uncertainty, and divergence of opinion. Journal of Finance, 32(4), $1151-1168$.

Nashikkar, A., Subrahmanyam, M.G., \& Mahanti, S. (2011). Liquidity and arbitrage in the market for credit risk. Journal of Financial and Quantitative Analysis, 46(3), 627-656.

Ni, S.X., \& Pan, J. (2015). Trading Puts and CDS on Stocks with Short Sale Ban Available at SSRN: https://ssrn.com/abstract=1572462

Norden, L., \& Weber, M. (2010). When senior meets junior: Information in credit default swap spreads of large banks. Financial Intermediation Research Society (FIRS) meetings paper, Financial Intermediation Research Society (FIRS), Florence, June.

Oehmke, M., \& Zawadowski, A. (2017). The anatomy of the CDS market. Review of Financial Studies, 30(1), 80-119.

Packer, F., \& Zhu, H. (2005). Contractual terms and CDS pricing. BIS Quarterly Review, March 2005, 89-100.

Pan, J., \& Singleton, K. (2008). Default and Recovery Implicit in the Term Structure of Sovereign CDS Spreads. Journal of Finance, 63(5), 2345-2384.

Qiu, J., \& Yu, F. (2012). Endogenous liquidity in credit derivatives. Journal of Financial Economics, 103(3), 611-631.

Shin, H.S. (2009). Reflections on Northern Rock: The bank run that heralded the financial crisis. Journal of Economic Perspectives, 23(1), 101-119. 
Sifat, I. M., \& Mohamad, A. (2015). Order imbalance and selling aggression under a shorting ban: Evidence from the UK. International Review of Financial Analysis, 42, 368-379.

Tang, D. \& Yan, H. (2008). Liquidity and Credit Default Swap Spreads, Working Paper, University of Hong Kong. 


\section{Table 1. Banned list after additions and removals}

Aberdeen Asset Management

Admiral Group

Alliance \& Leicester

Alliance Trust

Arbuthnot Banking Group

Aviva

Barclays

Bradford \& Bingley

Brit Insurance Holdings

Chesnara

Close Brothers Group

European Islamic Investment

F\&C Asset Management

Friends Provident

HBOS

HSBC Holdings

Investec

Islamic Bank of Britain

Just Retirement Holdings

Legal \& General Group

Lloyds TSB Group

Novae Group

Old Mutual

Provident Financial

Prudential

Rathbone Brothers

Royal Bank of Scotland

RSA Insurance Group

Schroders

St James Place

Standard Chartered

Standard Life

Tawa
14/7/08 takeover by Santander accepted, completed 10/10/08

26/9/08 "nationalized" and split into two

18/9/08 takeover by Lloyds announced, completed 19/1/09 
Table 2: CDS data set

\begin{tabular}{|l|l|l|}
\hline \multicolumn{1}{|c|}{ Company } & \multicolumn{1}{c|}{ From } & \multicolumn{1}{c|}{ To } \\
\hline Alliance \& Leicester & $09 / 08 / 2006$ & $10 / 10 / 2008$ \\
\hline Aviva & $09 / 08 / 2006$ & $17 / 05 / 2010$ \\
\hline Barclays & $09 / 08 / 2006$ & $17 / 05 / 2010$ \\
\hline Bradford \& Bingley & $09 / 08 / 2006$ & $26 / 09 / 2008$ \\
\hline HBOS & $09 / 08 / 2006$ & $14 / 01 / 2009$ \\
\hline HSBC Holdings & $09 / 08 / 2006$ & $17 / 05 / 2010$ \\
\hline Legal \& General Group & $09 / 08 / 2006$ & $17 / 05 / 2010$ \\
\hline Lloyds TSB Group & $09 / 08 / 2006$ & $17 / 05 / 2010$ \\
\hline Old Mutual & $09 / 08 / 2006$ & $17 / 05 / 2010$ \\
\hline Prudential & $09 / 08 / 2006$ & $17 / 05 / 2010$ \\
\hline Royal Bank of Scotland & $09 / 08 / 2006$ & $17 / 05 / 2010$ \\
\hline RSA Insurance Group & $09 / 08 / 2006$ & $17 / 05 / 2010$ \\
\hline Standard Chartered & $09 / 08 / 2006$ & $17 / 05 / 2010$ \\
\hline
\end{tabular}

Notes: CDS data of all companies are CMA CDS obtained from Datastream Professional. For the empirical analysis in this paper, we use daily data on 5-year euro-denominated CDS with modified-modified restructuring. 
Table 3: Granger causality test with confounding event dummies

\begin{tabular}{|c|c|c|c|c|c|c|c|}
\hline \multirow[t]{3}{*}{ Periods } & & Stock 1 & turn & $\mathrm{CDS} r$ & urn & \multicolumn{2}{|c|}{ Granger causality } \\
\hline & & \multicolumn{2}{|c|}{ (STK) } & \multicolumn{2}{|c|}{ (CDS) } & \multirow{2}{*}{$\begin{array}{c}\text { Chi2 } \\
\text { Stock } \rightarrow \text { CDS }\end{array}$} & \multirow{2}{*}{$\begin{array}{c}\text { Chi2 } \\
\text { CDS } \rightarrow \text { Stock }\end{array}$} \\
\hline & & Coef. & Std. Err. & Coef. & Std. Err. & & \\
\hline \multirow[t]{6}{*}{ Pre-crisis } & $\operatorname{STK}(-1)$ & 0.0031 & $(0.0226)$ & $-0.7516^{*}$ & $(0.4469)$ & \multirow[t]{6}{*}{$13.167 * * *$} & \multirow[t]{6}{*}{0.242} \\
\hline & $\operatorname{STK}(-2)$ & 0.0183 & $(0.0212)$ & $-1.5168 * * *$ & $(0.4564)$ & & \\
\hline & $\operatorname{STK}(-3)$ & $-0.0664 * * *$ & $(0.0238)$ & -0.4107 & $(0.3985)$ & & \\
\hline & $\operatorname{CDS}(-1)$ & 0.0003 & $(0.0008)$ & $-0.5122 * * *$ & $(0.0632)$ & & \\
\hline & $\operatorname{CDS}(-2)$ & 0.0001 & $(0.0008)$ & $-0.3117 * * *$ & $(0.0664)$ & & \\
\hline & $\operatorname{CDS}(-3)$ & 0.0002 & $(0.0008)$ & $-0.1907 * * *$ & $(0.0592)$ & & \\
\hline \multirow[t]{11}{*}{ Pre-disclosure } & $\operatorname{STK}(-1)$ & $-0.0689 *$ & $(0.0367)$ & $-0.3463 * * *$ & $(0.0800)$ & \multirow[t]{11}{*}{$53.058 * * *$} & \multirow[t]{11}{*}{6.088} \\
\hline & $\operatorname{STK}(-2)$ & -0.0514 & $(0.0315)$ & 0.1074 & $(0.0674)$ & & \\
\hline & $\operatorname{STK}(-3)$ & -0.0407 & $(0.0289)$ & $-0.1487 * *$ & $(0.0620)$ & & \\
\hline & $\operatorname{STK}(-4)$ & $-0.0763 * * *$ & $(0.0252)$ & -0.0156 & $(0.0533)$ & & \\
\hline & $\operatorname{STK}(-5)$ & -0.0254 & $(0.0221)$ & $-0.1681 * * *$ & $(0.0578)$ & & \\
\hline & $\operatorname{CDS}(-1)$ & -0.0132 & $(0.0115)$ & $0.0829 * * *$ & $(0.0230)$ & & \\
\hline & $\operatorname{CDS}(-2)$ & -0.0017 & $(0.0288)$ & 0.0509 & $(0.0397)$ & & \\
\hline & $\operatorname{CDS}(-3)$ & 0.0270 & $(0.0181)$ & -0.0439 & $(0.0350)$ & & \\
\hline & $\operatorname{CDS}(-4)$ & -0.0108 & $(0.0082)$ & $-0.0423 * *$ & $(0.0201)$ & & \\
\hline & $\operatorname{CDS}(-5)$ & -0.0083 & $(0.0084)$ & $-0.0398 * *$ & $(0.0161)$ & & \\
\hline & BEAR & $0.0136 * *$ & $(0.0065)$ & $-0.0471 * * *$ & $(0.0153)$ & & \\
\hline \multirow[t]{7}{*}{ Disclosure\#1 } & $\operatorname{STK}(-1)$ & -0.0807 & $(0.0690)$ & -0.0075 & $(0.1091)$ & \multirow[t]{7}{*}{$13.524 * * *$} & \multirow[t]{7}{*}{4.260} \\
\hline & $\operatorname{STK}(-2)$ & -0.0232 & $(0.0570)$ & 0.0479 & $(0.0700)$ & & \\
\hline & $\operatorname{STK}(-3)$ & 0.0031 & $(0.0632)$ & $-0.2424 * * *$ & $(0.0752)$ & & \\
\hline & $\operatorname{CDS}(-1)$ & -0.0591 & $(0.0523)$ & 0.0310 & $(0.0954)$ & & \\
\hline & $\operatorname{CDS}(-2)$ & 0.0478 & $(0.0470)$ & 0.0104 & $(0.0736)$ & & \\
\hline & $\operatorname{CDS}(-3)$ & $0.0904 *$ & $(0.0518)$ & $-0.1516^{* * *}$ & $(0.0583)$ & & \\
\hline & LEHM & $-0.0466 * * *$ & $(0.0149)$ & $0.0712 * * *$ & $(0.0257)$ & & \\
\hline \multirow[t]{8}{*}{ Ban } & $\operatorname{STK}(-1)$ & 0.0374 & $(0.0634)$ & -0.0554 & $(0.1225)$ & \multirow[t]{8}{*}{0.218} & \multirow[t]{8}{*}{$9.148 * * *$} \\
\hline & $\operatorname{STK}(-2)$ & $-0.2014 * * *$ & $(0.0588)$ & -0.0263 & $(0.1141)$ & & \\
\hline & $\operatorname{CDS}(-1)$ & $-0.0900^{*}$ & $(0.0492)$ & 0.0952 & $(0.0971)$ & & \\
\hline & $\operatorname{CDS}(-2)$ & 0.0626 & $(0.0480)$ & -0.1386 & $(0.1084)$ & & \\
\hline & PSF & 0.0953 & $(0.2454)$ & 0.5714 & $(0.5210)$ & & \\
\hline & TAKE & -0.0136 & $(0.0093)$ & -0.0110 & $(0.0111)$ & & \\
\hline & LEHM & 0.0806 & $(0.0631)$ & -0.0014 & (0.1288) & & \\
\hline & TARP & -0.0532 & $(0.0579)$ & 0.1219 & $(0.1243)$ & & \\
\hline
\end{tabular}


Table 3: Granger causality test with confounding event dummies (continued)

\begin{tabular}{|c|c|c|c|c|c|c|c|}
\hline \multirow[t]{3}{*}{ Periods } & & Stock & turn & CDS & urn & \multicolumn{2}{|c|}{ Granger causality } \\
\hline & & \multicolumn{2}{|c|}{ (STK) } & \multicolumn{2}{|c|}{$(\mathrm{CDS})$} & \multirow{2}{*}{$\begin{array}{c}\text { Chi2 } \\
\text { Stock } \rightarrow \text { CDS }\end{array}$} & \multirow{2}{*}{$\begin{array}{c}\text { Chi2 } \\
\text { CDS } \rightarrow \text { Stock }\end{array}$} \\
\hline & & Coef. & Std. Err. & Coef. & Std. Err. & & \\
\hline \multirow[t]{5}{*}{ Disclosure\#2 } & $\operatorname{STK}(-1)$ & $0.0861 *$ & $(0.0468)$ & $-0.1627 * * *$ & $(0.0229)$ & \multirow[t]{5}{*}{$54.334 * * *$} & \multirow[t]{5}{*}{3.523} \\
\hline & $\operatorname{STK}(-2)$ & 0.0136 & $(0.0555)$ & $-0.0789 * * *$ & $(0.0283)$ & & \\
\hline & $\operatorname{CDS}(-1)$ & $0.1090^{*}$ & $(0.0581)$ & 0.0240 & $(0.0439)$ & & \\
\hline & $\operatorname{CDS}(-2)$ & -0.0141 & $(0.0513)$ & 0.0210 & $(0.0397)$ & & \\
\hline & $\begin{array}{l}\text { PSF } \\
\text { APS }\end{array}$ & $\begin{array}{l}\text { (omitted) } \\
0.0288\end{array}$ & $(0.0230)$ & $\begin{array}{l}\text { (omitted) } \\
-0.0133\end{array}$ & $(0.0084)$ & & \\
\hline \multirow[t]{9}{*}{ Post-disclosure } & $\operatorname{STK}(-1)$ & 0.0014 & $(0.0277)$ & $-0.2195 * * *$ & $(0.0505)$ & \multirow[t]{9}{*}{$30.689 * * *$} & \multirow[t]{9}{*}{$8.144 *$} \\
\hline & $\operatorname{STK}(-2)$ & -0.0346 & $(0.0250)$ & $-0.1128 * *$ & $(0.0467)$ & & \\
\hline & $\operatorname{STK}(-3)$ & $-0.0734 * * *$ & $(0.0241)$ & -0.0578 & $(0.0361)$ & & \\
\hline & STK $(-4)$ & 0.0194 & $(0.0241)$ & $0.1003^{*}$ & $(0.0523)$ & & \\
\hline & $\operatorname{CDS}(-1)$ & 0.0072 & $(0.0052)$ & -0.0086 & $(0.0150)$ & & \\
\hline & $\operatorname{CDS}(-2)$ & 0.0052 & $(0.0034)$ & -0.0383 & $(0.0449)$ & & \\
\hline & $\operatorname{CDS}(-3)$ & -0.0017 & $(0.0045)$ & 0.0408 & $(0.0485)$ & & \\
\hline & $\operatorname{CDS}(-4)$ & $0.0057 * *$ & $(0.0028)$ & -0.0038 & $(0.0105)$ & & \\
\hline & $\begin{array}{l}\text { PSF } \\
\text { APS }\end{array}$ & $\begin{array}{l}\text { (omitted) } \\
0.0033\end{array}$ & $(0.0081)$ & $\begin{array}{l}\text { (omitted) } \\
-0.0176\end{array}$ & $(0.0086)$ & & \\
\hline \multirow[t]{12}{*}{ Whole sample } & $\operatorname{STK}(-1)$ & 0.0085 & $(0.0518)$ & $-0.3954 * * *$ & $(0.0669)$ & \multirow[t]{12}{*}{$35.548 * * *$} & \multirow[t]{12}{*}{3.866} \\
\hline & $\operatorname{STK}(-2)$ & $-0.0854 * *$ & $(0.0383)$ & $-0.2308 * * *$ & $(0.0615)$ & & \\
\hline & $\operatorname{STK}(-3)$ & -0.0532 & $(0.0516)$ & $-0.2154 * * *$ & $(0.0668)$ & & \\
\hline & $\operatorname{CDS}(-1)$ & 0.0020 & $(0.0046)$ & $-0.4106^{* * *}$ & $(0.0546)$ & & \\
\hline & $\operatorname{CDS}(-2)$ & 0.0046 & $(0.0058)$ & $-0.2165 * * *$ & $(0.0553)$ & & \\
\hline & $\operatorname{CDS}(-3)$ & 0.0059 & $(0.0050)$ & $-0.1277 * *$ & $(0.0505)$ & & \\
\hline & BEAR & 0.0401 & $(0.0467)$ & 0.0127 & $(0.0503)$ & & \\
\hline & LEHM & 0.0455 & $(0.0701)$ & $0.1421 *$ & $(0.0753)$ & & \\
\hline & TARP & -0.0238 & $(0.0814)$ & 0.0729 & $(0.0795)$ & & \\
\hline & PSF & 0.1863 & $(0.3128)$ & $0.5570^{*}$ & $(0.3176)$ & & \\
\hline & TAKE & -0.0099 & $(0.0174)$ & $-0.0468 * * *$ & $(0.0174)$ & & \\
\hline & APS & 0.0107 & $(0.0096)$ & $-0.0169 *$ & $(0.0088)$ & & \\
\hline
\end{tabular}

Notes: The table reports Granger causality tests based on a panel autoregressive (pVAR) model with robust standard errors and lag selection by MAIC. The results of pVAR are based on daily data on 5-year euro-denominated senior CDS with modified-modified restructuring. The first log-difference of CDS mid prices is used as the proxy for CDS returns. The stock return is defined as the first log-difference of the closing prices. The Helmert transformation is used to remove panel-specific fixed effects. For the major US events including the Bear Stern collapse (BEAR), the Lehman Brothers collapse (LEHM), and the announcement of Troubled Asset Relief Program (TARP), dummy variable for each event equals one during the 5 business days following the event day. The government's public sector finance (PSF) is a dummy variable that equals one from 13/10/08, the date of the announcement of the scheme, to the end of the sample for Lloyds and RBS and the date of acquisition for HBOS. The announcement of takeovers (TAKE) is a dummy variable that takes the value of one for the targets from the date of the announcement to the delisting: from 14/7/08 for Alliance and Leicester and from 13/10/08 for HBOS. The asset protection scheme (APS) is a dummy variable that takes the value of one for RBS from March to the end of the sample, and one for Lloyds from March to 3/11/09 when Lloyds exited the scheme. *,**, *** indicate significance at the 10,5 and 1 percent levels, respectively. 
Table 4: Median stock bid-ask spreads

\begin{tabular}{|c|c|c|c|c|c|c|c|c|c|}
\hline \multirow[t]{2}{*}{ Firm } & \multicolumn{7}{|c|}{ Period } & \multicolumn{2}{|c|}{ Tests for equality of medians } \\
\hline & Pre-crisis & Pre-disclosure & Disclosure\#1 & Ban & Disclosure\#2 & Post-disclosure & Whole sample & $\begin{array}{c}\text { Disclosure\#1 \& } \\
\text { Ban } \\
\mathrm{Chi}^{2}(1)\end{array}$ & $\begin{array}{c}\text { Ban \& } \\
\text { Disclosure\#2 } \\
\mathrm{Chi}^{2}(1)\end{array}$ \\
\hline \multicolumn{10}{|c|}{ Panel A: Banned stocks with CDS } \\
\hline Alliance \& Leicester & $0.18 \%$ & $0.10 \%$ & $0.18 \%$ & NA & NA & NA & $0.16 \%$ & NA & NA \\
\hline Aviva & $0.12 \%$ & $0.08 \%$ & $0.10 \%$ & $0.14 \%$ & $0.10 \%$ & $0.07 \%$ & $0.08 \%$ & 2.53 & $5.83 * *$ \\
\hline Barclays & $0.07 \%$ & $0.08 \%$ & $0.08 \%$ & $0.11 \%$ & $0.11 \%$ & $0.03 \%$ & $0.07 \%$ & $5.09 * *$ & 0.01 \\
\hline Bradford \& Bingley & $0.17 \%$ & $0.15 \%$ & $0.50 \%$ & NA & NA & NA & $0.17 \%$ & NA & NA \\
\hline HBOS & $0.09 \%$ & $0.07 \%$ & $0.09 \%$ & $0.33 \%$ & NA & NA & $0.09 \%$ & $48.31 * * *$ & NA \\
\hline HSBC Holdings & $0.05 \%$ & $0.06 \%$ & $0.03 \%$ & $0.04 \%$ & $0.05 \%$ & $0.03 \%$ & $0.05 \%$ & $16.11 * * *$ & 2.18 \\
\hline Legal \& General Group & $0.17 \%$ & $0.08 \%$ & $0.10 \%$ & $0.28 \%$ & $0.22 \%$ & $0.08 \%$ & $0.13 \%$ & $45.85 * * *$ & $9.22 * * *$ \\
\hline Lloyds TSB Group & $0.09 \%$ & $0.06 \%$ & $0.08 \%$ & $0.16 \%$ & $0.20 \%$ & $0.08 \%$ & $0.09 \%$ & $24.19 * * *$ & $2.95 *$ \\
\hline Old Mutual & $0.19 \%$ & $0.09 \%$ & $0.11 \%$ & $0.40 \%$ & $0.28 \%$ & $0.09 \%$ & $0.15 \%$ & $39.05 * * *$ & $7.43 * * *$ \\
\hline Prudential & $0.13 \%$ & $0.08 \%$ & $0.09 \%$ & $0.15 \%$ & $0.12 \%$ & $0.09 \%$ & $0.09 \%$ & $18.09 * * *$ & 2.20 \\
\hline Royal Bank of Scotland & $0.08 \%$ & $0.07 \%$ & $0.11 \%$ & $0.22 \%$ & $0.43 \%$ & $0.09 \%$ & $0.10 \%$ & $88.98 * * *$ & $28.85 * * *$ \\
\hline RSA Insurance Group & $0.17 \%$ & $0.08 \%$ & $0.08 \%$ & $0.15 \%$ & $0.08 \%$ & $0.08 \%$ & $0.13 \%$ & $21.03 * * *$ & $7.43 * * *$ \\
\hline Standard Chartered & $0.14 \%$ & $0.06 \%$ & $0.07 \%$ & $0.15 \%$ & $0.08 \%$ & $0.07 \%$ & $0.08 \%$ & $43.32 * * *$ & $12.29 * * *$ \\
\hline All firms & $0.13 \%$ & $0.08 \%$ & $0.10 \%$ & $0.18 \%$ & $0.16 \%$ & $0.08 \%$ & $0.09 \%$ & $245.39 * * *$ & $3.58^{*}$ \\
\hline
\end{tabular}


Table 4: Median stock bid-ask spreads (continued)

\begin{tabular}{|c|c|c|c|c|c|c|c|c|c|}
\hline \multirow[t]{2}{*}{ Firm } & \multicolumn{7}{|c|}{ Period } & \multicolumn{2}{|c|}{ Tests for equality of medians } \\
\hline & Pre-crisis & Pre-disclosure & Disclosure\#1 & Ban & Disclosure\#2 & Post-disclosure & Whole sample & $\begin{array}{c}\text { Disclosure\#1 \& } \\
\text { Ban } \\
\mathrm{Chi}^{2}(1)\end{array}$ & $\begin{array}{c}\text { Ban \& } \\
\text { Disclosure\#2 } \\
\mathrm{Chi}^{2}(1)\end{array}$ \\
\hline \multicolumn{10}{|l|}{ Panel B: Other banned stocks } \\
\hline Aberdeen Asset Management & $0.27 \%$ & $0.18 \%$ & $0.21 \%$ & $0.52 \%$ & $0.39 \%$ & $0.19 \%$ & $0.22 \%$ & $5.09 * *$ & 1.36 \\
\hline Admiral Group & $0.20 \%$ & $0.10 \%$ & $0.10 \%$ & $0.20 \%$ & $0.12 \%$ & $0.09 \%$ & $0.12 \%$ & $12.87 * * *$ & $3.21 *$ \\
\hline Alliance Trust & $0.67 \%$ & $0.22 \%$ & $0.24 \%$ & $0.41 \%$ & $0.36 \%$ & $0.19 \%$ & $0.29 \%$ & $12.87 * * *$ & $3.21 *$ \\
\hline Arbuthnot Banking Group & $2.79 \%$ & $2.86 \%$ & $3.08 \%$ & $6.35 \%$ & $11.76 \%$ & $5.26 \%$ & $3.81 \%$ & $73.58 * * *$ & $104.02 * * *$ \\
\hline Brit Insurance Holdings & $0.27 \%$ & $0.11 \%$ & $0.16 \%$ & $0.56 \%$ & $0.28 \%$ & $0.15 \%$ & $0.20 \%$ & $21.03 * * *$ & $7.43 * * *$ \\
\hline Chesnara & $1.85 \%$ & $0.91 \%$ & $1.38 \%$ & $2.34 \%$ & $1.56 \%$ & $1.28 \%$ & $1.39 \%$ & $3.70 *$ & $3.21 *$ \\
\hline Close Brothers Group & $0.21 \%$ & $0.11 \%$ & $0.10 \%$ & $0.49 \%$ & $0.16 \%$ & $0.15 \%$ & $0.16 \%$ & $35.00 * * *$ & $18.34 * * *$ \\
\hline European Islamic Investment & $4.88 \%$ & $6.45 \%$ & $7.54 \%$ & $11.76 \%$ & $24.00 \%$ & $13.33 \%$ & $7.41 \%$ & $25.14 * * *$ & $37.82 * * *$ \\
\hline F\&C Asset Management & $0.42 \%$ & $0.24 \%$ & $0.58 \%$ & $1.61 \%$ & $1.31 \%$ & $0.29 \%$ & $0.37 \%$ & $12.87 * * *$ & 0.73 \\
\hline Friends Provident & $0.23 \%$ & $0.11 \%$ & $0.11 \%$ & $0.35 \%$ & $0.15 \%$ & $0.17 \%$ & $0.15 \%$ & $24.19 * * *$ & $11.21 * * *$ \\
\hline Investec & $0.25 \%$ & $0.10 \%$ & $0.14 \%$ & $0.47 \%$ & $0.24 \%$ & $0.11 \%$ & $0.16 \%$ & $15.37 * * *$ & $7.43 * * *$ \\
\hline Islamic Bank of Britain & $12.05 \%$ & $4.65 \%$ & $4.44 \%$ & $12.24 \%$ & $15.38 \%$ & $28.57 \%$ & $10.53 \%$ & $111.82 * * *$ & $3.20 *$ \\
\hline Just Retirement Holdings & $2.45 \%$ & $0.76 \%$ & $1.72 \%$ & $2.11 \%$ & $2.63 \%$ & $1.26 \%$ & $1.53 \%$ & 0.86 & 1.36 \\
\hline Novae Group & $3.51 \%$ & $0.74 \%$ & $1.03 \%$ & $1.71 \%$ & $1.64 \%$ & $1.24 \%$ & $1.45 \%$ & 0.86 & 0.73 \\
\hline Provident Financial & $0.23 \%$ & $0.12 \%$ & $0.12 \%$ & $0.17 \%$ & $0.19 \%$ & $0.11 \%$ & $0.13 \%$ & 1.58 & 0.49 \\
\hline Rathbone Brothers & $1.20 \%$ & $0.32 \%$ & $0.32 \%$ & $1.12 \%$ & $0.88 \%$ & $0.60 \%$ & $0.66 \%$ & $31.18 * * *$ & 2.19 \\
\hline Schroders & $0.22 \%$ & $0.10 \%$ & $0.11 \%$ & $0.28 \%$ & $0.14 \%$ & $0.10 \%$ & $0.14 \%$ & $18.09 * * *$ & $5.83 * *$ \\
\hline St James Place & $0.30 \%$ & $0.14 \%$ & $0.12 \%$ & $0.79 \%$ & $0.41 \%$ & $0.26 \%$ & $0.24 \%$ & $21.03 * * *$ & $5.83 * *$ \\
\hline Standard Life & $0.25 \%$ & $0.11 \%$ & $0.12 \%$ & $0.29 \%$ & $0.18 \%$ & $0.10 \%$ & $0.15 \%$ & $12.87 * * *$ & $3.21 *$ \\
\hline Tawa & $3.66 \%$ & $3.69 \%$ & $4.74 \%$ & $7.63 \%$ & $10.99 \%$ & $9.52 \%$ & $7.63 \%$ & $110.87 * * *$ & $68.77 * * *$ \\
\hline All firms & $0.42 \%$ & $0.22 \%$ & $0.29 \%$ & $0.91 \%$ & $0.56 \%$ & $0.30 \%$ & $0.36 \%$ & $155.85 * * *$ & $40.83 * * *$ \\
\hline
\end{tabular}

Notes: This table presents median bid-ask spreads for the banned CDS and other stocks. The bid-ask spread is defined as $100 *($ ask-bid $) /($ ask + bid $) / 2 . *, * *, * * *$ indicate significance at the 10,5 and 1 percent levels, respectively. 
Table 5: Median CDS bid-ask spreads

\begin{tabular}{|c|c|c|c|c|c|c|c|c|c|}
\hline \multirow[t]{2}{*}{ Firm } & \multicolumn{7}{|c|}{ Period } & \multicolumn{2}{|c|}{ Tests for equality of medians } \\
\hline & Pre-crisis & Pre-disclosure & Disclosure\#1 & Ban & Disclosure\#2 & Post-disclosure & Whole sample & $\begin{array}{c}\text { Disclosure } \# 1 \\
\& \\
\text { Ban } \\
\mathrm{Chi}^{2}(1)\end{array}$ & $\begin{array}{c}\text { Ban \& } \\
\text { Disclosure\#2 } \\
\text { Chi }^{2}(1)\end{array}$ \\
\hline \multicolumn{10}{|l|}{ Panel A: Senior CDS } \\
\hline Alliance \& Leicester & $\begin{array}{c}2.91 \\
(30.4 \%)\end{array}$ & $\begin{array}{c}20.00 \\
(12.4 \%)\end{array}$ & $\begin{array}{c}15.00 \\
(12.7 \%)\end{array}$ & $\begin{array}{l}\text { NA } \\
\text { NA }\end{array}$ & $\begin{array}{l}\text { NA } \\
\text { NA }\end{array}$ & $\begin{array}{l}\text { NA } \\
\text { NA }\end{array}$ & $\begin{array}{c}4.17 \\
(18.8 \%)\end{array}$ & NA & NA \\
\hline Aviva & $\begin{array}{c}2.00 \\
(26.7 \%)\end{array}$ & $\begin{array}{c}6.00 \\
(9.9 \%)\end{array}$ & $\begin{array}{c}6.00 \\
(5.2 \%)\end{array}$ & $\begin{array}{c}12.00 \\
(7.3 \%)\end{array}$ & $\begin{array}{c}19.54 \\
(6.2 \%)\end{array}$ & $\begin{array}{c}5.00 \\
(5.2 \%)\end{array}$ & $\begin{array}{c}5.00 \\
(7.7 \%)\end{array}$ & $45.33 * * *$ & $21.09 * * *$ \\
\hline Barclays & $\begin{array}{c}2.00 \\
(28.6 \%) \\
\end{array}$ & $\begin{array}{c}5.00 \\
(8.5 \%) \\
\end{array}$ & $\begin{array}{c}5.00 \\
(4.1 \%) \\
\end{array}$ & $\begin{array}{c}10.00 \\
(6.7 \%) \\
\end{array}$ & $\begin{array}{c}10.00 \\
(5.3 \%) \\
\end{array}$ & $\begin{array}{c}4.67 \\
(4.8 \%) \\
\end{array}$ & $\begin{array}{c}5.00 \\
(6.7 \%) \\
\end{array}$ & $77.77 * * *$ & $<0.01$ \\
\hline Bradford \& Bingley & $\begin{array}{c}3.29 \\
(16.1 \%) \\
\end{array}$ & $\begin{array}{c}50.00 \\
(27.0 \%) \\
\end{array}$ & $\begin{array}{c}50.00 \\
(11.3 \%) \\
\end{array}$ & $\begin{array}{l}\text { NA } \\
\text { NA }\end{array}$ & $\begin{array}{l}\text { NA } \\
\text { NA }\end{array}$ & $\begin{array}{l}\text { NA } \\
\text { NA }\end{array}$ & $\begin{array}{c}4.02 \\
(18.0 \%) \\
\end{array}$ & NA & NA \\
\hline HBOS & $\begin{array}{c}2.00 \\
(33.3 \%)\end{array}$ & $\begin{array}{c}5.00 \\
(7.3 \%)\end{array}$ & $\begin{array}{c}10.00 \\
(5.5 \%)\end{array}$ & $\begin{array}{c}10.00 \\
(8.7 \%)\end{array}$ & $\begin{array}{l}\text { NA } \\
\text { NA }\end{array}$ & $\begin{array}{l}\text { NA } \\
\text { NA }\end{array}$ & $\begin{array}{c}5.00 \\
(11.3 \%)\end{array}$ & $3.55^{*}$ & NA \\
\hline HSBC Holdings & $\begin{array}{c}2.00 \\
(31.3 \%) \\
\end{array}$ & $\begin{array}{c}5.00 \\
(10.7 \%) \\
\end{array}$ & $\begin{array}{c}5.00 \\
(7.9 \%)\end{array}$ & $\begin{array}{c}10.00 \\
(10.3 \%) \\
\end{array}$ & $\begin{array}{c}10.00 \\
(7.6 \%) \\
\end{array}$ & $\begin{array}{c}4.68 \\
(7.1 \%) \\
\end{array}$ & $\begin{array}{c}5.00 \\
(9.6 \%) \\
\end{array}$ & $80.26^{* * *}$ & 1.39 \\
\hline Legal \& General Group & $\begin{array}{c}3.00 \\
(23.5 \%)\end{array}$ & $\begin{array}{c}9.00 \\
(13.7 \%)\end{array}$ & $\begin{array}{c}8.00 \\
(9.3 \%)\end{array}$ & $\begin{array}{c}28.00 \\
(9.6 \%)\end{array}$ & $\begin{array}{c}57.15 \\
(9.9 \%) \\
\end{array}$ & $\begin{array}{c}19.45 \\
(8.6 \%) \\
\end{array}$ & $\begin{array}{c}9.87 \\
(12.2 \%) \\
\end{array}$ & $76.00 * * *$ & $52.05 * * *$ \\
\hline Lloyds TSB Group & $\begin{array}{c}2.00 \\
(41.7 \%) \\
\end{array}$ & $\begin{array}{c}5.00 \\
(13.1 \%)\end{array}$ & $\begin{array}{c}5.00 \\
(6.1 \%) \\
\end{array}$ & $\begin{array}{c}10.00 \\
(10.0 \%)\end{array}$ & $\begin{array}{c}10.00 \\
(5.6 \%) \\
\end{array}$ & $\begin{array}{c}4.95 \\
(3.9 \%) \\
\end{array}$ & $\begin{array}{c}5.00 \\
(9.5 \%) \\
\end{array}$ & $77.77 * * *$ & 0.08 \\
\hline Old Mutual & $\begin{array}{c}4.00 \\
(25.6 \%) \\
\end{array}$ & $\begin{array}{c}10.00 \\
(10.3 \%)\end{array}$ & $\begin{array}{c}10.00 \\
(7.4 \%) \\
\end{array}$ & $\begin{array}{c}50.00 \\
(9.1 \%) \\
\end{array}$ & $\begin{array}{c}176.82 \\
(11.8 \%) \\
\end{array}$ & $\begin{array}{c}22.99 \\
(8.5 \%) \\
\end{array}$ & $\begin{array}{c}12.00 \\
(11.0 \%) \\
\end{array}$ & $105.89 * * *$ & $43.80 * * *$ \\
\hline Prudential & $\begin{array}{c}2.00 \\
(20.2 \%)\end{array}$ & $\begin{array}{c}6.00 \\
(11.8 \%) \\
\end{array}$ & $\begin{array}{c}6.00 \\
(6.9 \%) \\
\end{array}$ & $\begin{array}{c}22.00 \\
(7.0 \%) \\
\end{array}$ & $\begin{array}{c}50.00 \\
(9.2 \%) \\
\end{array}$ & $\begin{array}{c}10.12 \\
(9.6 \%) \\
\end{array}$ & $\begin{array}{c}7.00 \\
(11.1 \%) \\
\end{array}$ & $92.63 * * *$ & $80.16^{* * *}$ \\
\hline Royal Bank of Scotland & $\begin{array}{c}2.00 \\
(33.3 \%) \\
\end{array}$ & $\begin{array}{c}5.00 \\
(8.3 \%) \\
\end{array}$ & $\begin{array}{c}5.00 \\
(4.7 \%) \\
\end{array}$ & $\begin{array}{c}10.00 \\
(7.4 \%) \\
\end{array}$ & $\begin{array}{c}10.00 \\
(5.4 \%) \\
\end{array}$ & $\begin{array}{c}4.91 \\
(3.6 \%) \\
\end{array}$ & $\begin{array}{c}5.00 \\
(7.1 \%) \\
\end{array}$ & $64.11 * * *$ & $<0.01$ \\
\hline RSA Insurance Group & $\begin{array}{c}2.00 \\
(20.0 \%) \\
\end{array}$ & $\begin{array}{c}10.00 \\
(15.3 \%)\end{array}$ & $\begin{array}{c}6.00 \\
(11.3 \%) \\
\end{array}$ & $\begin{array}{c}12.00 \\
(11.8 \%) \\
\end{array}$ & $\begin{array}{c}10.00 \\
(10.7 \%) \\
\end{array}$ & $\begin{array}{c}5.11 \\
(10.1 \%) \\
\end{array}$ & $\begin{array}{c}6.00 \\
(14.1 \%) \\
\end{array}$ & $60.68 * * *$ & $45.59 * * *$ \\
\hline Standard Chartered & $\begin{array}{c}3.00 \\
(32.8 \%)\end{array}$ & $\begin{array}{c}8.00 \\
(12.1 \%)\end{array}$ & $\begin{array}{c}5.00 \\
(7.2 \%)\end{array}$ & $\begin{array}{c}18.00 \\
(11.3 \%)\end{array}$ & $\begin{array}{c}24.00 \\
(10.1 \%)\end{array}$ & $\begin{array}{c}8.13 \\
(8.7 \%)\end{array}$ & $\begin{array}{c}5.35 \\
(11.8 \%)\end{array}$ & $111.82 * * *$ & $67.05 * * *$ \\
\hline All firms & $\begin{array}{c}2.00 \\
(28.6 \%)\end{array}$ & $\begin{array}{c}6.00 \\
(11.6 \%)\end{array}$ & $\begin{array}{c}6.00 \\
(7.2 \%)\end{array}$ & $\begin{array}{l}12.00 \\
(9.0 \%)\end{array}$ & $\begin{array}{c}12.00 \\
(8.3 \%)\end{array}$ & $\begin{array}{c}5.56 \\
(6.9 \%)\end{array}$ & $\begin{array}{c}5.00 \\
(11.1 \%)\end{array}$ & $238.48 * * *$ & 1.33 \\
\hline
\end{tabular}


Table 5: Median CDS bid-ask spreads (continued)

\begin{tabular}{|c|c|c|c|c|c|c|c|c|c|}
\hline \multirow[t]{2}{*}{ Firm } & \multicolumn{7}{|c|}{ Period } & \multicolumn{2}{|c|}{ Tests for equality of medians } \\
\hline & Pre-crisis & Pre-disclosure & Disclosure\#1 & Ban & Disclosure\#2 & Post-disclosure & Whole sample & $\begin{array}{c}\text { Disclosure } \# 1 \& \\
\text { Ban } \\
\operatorname{Chi}^{2}(1)\end{array}$ & $\begin{array}{c}\text { Ban \& } \\
\text { Disclosure\#2 } \\
\mathrm{Chi}^{2}(1)\end{array}$ \\
\hline \multicolumn{10}{|c|}{ Panel B: Subordinate CDS } \\
\hline Alliance \& Leicester & $\begin{array}{c}3.31 \\
(15.7 \%) \\
\end{array}$ & $\begin{array}{c}3.72 \\
(11.4 \%) \\
\end{array}$ & $\begin{array}{c}30.00 \\
(13.6 \%) \\
\end{array}$ & $\begin{array}{l}\text { NA } \\
\text { NA } \\
\end{array}$ & $\begin{array}{l}\text { NA } \\
\text { NA } \\
\end{array}$ & $\begin{array}{l}\text { NA } \\
\text { NA } \\
\end{array}$ & $\begin{array}{c}3.72 \\
(12.5 \%) \\
\end{array}$ & NA & NA \\
\hline Aviva & $\begin{array}{c}2.00 \\
(14.1 \%) \\
\end{array}$ & $\begin{array}{c}8.00 \\
(8.3 \%) \\
\end{array}$ & $\begin{array}{c}9.00 \\
(5.1 \%) \\
\end{array}$ & $\begin{array}{c}20.00 \\
(6.5 \%) \\
\end{array}$ & $\begin{array}{c}29.98 \\
(6.1 \%) \\
\end{array}$ & $\begin{array}{c}9.70 \\
(5.8 \%) \\
\end{array}$ & $\begin{array}{c}9.00 \\
(7.1 \%) \\
\end{array}$ & $74.08 * * *$ & $22.55 * * *$ \\
\hline Barclays & $\begin{array}{c}2.00 \\
(21.7 \%) \\
\end{array}$ & $\begin{array}{c}8.00 \\
(8.2 \%) \\
\end{array}$ & $\begin{array}{c}10.00 \\
(4.9 \%) \\
\end{array}$ & $\begin{array}{c}17.00 \\
(7.3 \%) \\
\end{array}$ & $\begin{array}{c}20.00 \\
(7.1 \%) \\
\end{array}$ & $\begin{array}{c}7.32 \\
(4.9 \%) \\
\end{array}$ & $\begin{array}{c}7.28 \\
(7.3 \%) \\
\end{array}$ & $80.26 * * *$ & $38.02 * * *$ \\
\hline Bradford \& Bingley & $\begin{array}{c}3.54 \\
(12.9 \%)\end{array}$ & $\begin{array}{c}20.00 \\
(11.1 \%)\end{array}$ & $\begin{array}{c}100.00 \\
(13.3 \%)\end{array}$ & $\begin{array}{l}\text { NA } \\
\text { NA }\end{array}$ & $\begin{array}{l}\text { NA } \\
\text { NA }\end{array}$ & $\begin{array}{l}\text { NA } \\
\text { NA }\end{array}$ & $\begin{array}{c}4.01 \\
(11.1 \%) \\
\end{array}$ & NA & NA \\
\hline HBOS & $\begin{array}{c}2.00 \\
(21.7 \%) \\
\end{array}$ & $\begin{array}{c}10.00 \\
(7.4 \%) \\
\end{array}$ & $\begin{array}{c}12.00 \\
(4.4 \%) \\
\end{array}$ & $\begin{array}{c}17.00 \\
(9.5 \%) \\
\end{array}$ & $\begin{array}{l}\text { NA } \\
\text { NA }\end{array}$ & $\begin{array}{l}\text { NA } \\
\text { NA }\end{array}$ & $\begin{array}{c}6.00 \\
(10.2 \%) \\
\end{array}$ & $18.90 * * *$ & NA \\
\hline HSBC Holdings & $\begin{array}{c}2.00 \\
(22.2 \%) \\
\end{array}$ & $\begin{array}{c}8.00 \\
(9.5 \%) \\
\end{array}$ & $\begin{array}{c}10.00 \\
(9.1 \%)\end{array}$ & $\begin{array}{c}15.00 \\
(10.1 \%)\end{array}$ & $\begin{array}{c}20.00 \\
(9.7 \%)\end{array}$ & $\begin{array}{c}6.02 \\
(6.8 \%) \\
\end{array}$ & $\begin{array}{c}6.00 \\
(10.0 \%) \\
\end{array}$ & $81.24 * * *$ & $25.20 * * *$ \\
\hline Legal \& General Group & $\begin{array}{c}3.00 \\
(20.7 \%) \\
\end{array}$ & $\begin{array}{c}10.00 \\
(12.1 \%)\end{array}$ & $\begin{array}{c}10.00 \\
(8.7 \%) \\
\end{array}$ & $\begin{array}{c}27.00 \\
(8.5 \%) \\
\end{array}$ & $\begin{array}{c}98.35 \\
(9.1 \%) \\
\end{array}$ & $\begin{array}{c}27.91 \\
(9.9 \%) \\
\end{array}$ & $\begin{array}{c}16.31 \\
(11.2 \%) \\
\end{array}$ & $111.82 * * *$ & $62.16^{* * *}$ \\
\hline Lloyds TSB Group & $\begin{array}{c}2.00 \\
(26.7 \%)\end{array}$ & $\begin{array}{c}8.00 \\
(10.8 \%)\end{array}$ & $\begin{array}{c}10.00 \\
(6.8 \%)\end{array}$ & $\begin{array}{c}16.00 \\
(10.4 \%)\end{array}$ & $\begin{array}{c}20.41 \\
(7.5 \%)\end{array}$ & $\begin{array}{c}11.24 \\
(4.5 \%)\end{array}$ & $\begin{array}{c}10.00 \\
(9.2 \%)\end{array}$ & $78.80 * * *$ & $42.45 * * *$ \\
\hline Old Mutual & $\begin{array}{c}5.00 \\
(18.2 \%) \\
\end{array}$ & $\begin{array}{c}11.00 \\
(16.7 \%)\end{array}$ & $\begin{array}{c}15.00 \\
(7.8 \%)\end{array}$ & $\begin{array}{c}100.00 \\
(10.6 \%)\end{array}$ & $\begin{array}{c}168.00 \\
(10.3 \%)\end{array}$ & $\begin{array}{c}51.45 \\
(14.0 \%) \\
\end{array}$ & $\begin{array}{c}20.00 \\
(14.1 \%)\end{array}$ & $94.93 * * *$ & $82.96^{* * *}$ \\
\hline Prudential & $\begin{array}{c}3.00 \\
(15.2 \%)\end{array}$ & $\begin{array}{c}10.00 \\
(11.3 \%)\end{array}$ & $\begin{array}{c}10.00 \\
(7.7 \%)\end{array}$ & $\begin{array}{c}26.00 \\
(7.2 \%) \\
\end{array}$ & $\begin{array}{c}50.00 \\
(9.0 \%) \\
\end{array}$ & $\begin{array}{c}10.39 \\
(9.2 \%)\end{array}$ & $\begin{array}{c}10.00 \\
(10.3 \%) \\
\end{array}$ & $77.60 * * *$ & $48.00 * * *$ \\
\hline Royal Bank of Scotland & $\begin{array}{c}2.00 \\
(22.2 \%)\end{array}$ & $\begin{array}{c}8.00 \\
(8.8 \%)\end{array}$ & $\begin{array}{c}10.00 \\
(5.2 \%)\end{array}$ & $\begin{array}{c}15.00 \\
(7.0 \%)\end{array}$ & $\begin{array}{c}25.00 \\
(5.9 \%)\end{array}$ & $\begin{array}{c}11.83 \\
(4.1 \%)\end{array}$ & $\begin{array}{c}10.00 \\
(7.0 \%)\end{array}$ & $59.89 * * *$ & $45.00 * * *$ \\
\hline RSA Insurance Group & $\begin{array}{c}3.00 \\
(15.4 \%) \\
\end{array}$ & $\begin{array}{c}10.00 \\
(11.1 \%)\end{array}$ & $\begin{array}{l}10.00 \\
(7.9 \%) \\
\end{array}$ & $\begin{array}{c}20.00 \\
(10.5 \%) \\
\end{array}$ & $\begin{array}{c}20.00 \\
(10.0 \%) \\
\end{array}$ & $\begin{array}{c}9.94 \\
(10.2 \%) \\
\end{array}$ & $\begin{array}{c}9.97 \\
(11.0 \%) \\
\end{array}$ & $24.78 * * *$ & 1.70 \\
\hline Standard Chartered & $\begin{array}{c}2.00 \\
(16.7 \%) \\
\end{array}$ & $\begin{array}{c}10.00 \\
(9.7 \%) \\
\end{array}$ & $\begin{array}{c}10.00 \\
(7.2 \%) \\
\end{array}$ & $\begin{array}{c}22.00 \\
(8.4 \%) \\
\end{array}$ & $\begin{array}{c}30.00 \\
(8.0 \%) \\
\end{array}$ & $\begin{array}{c}9.87 \\
(7.7 \%) \\
\end{array}$ & $\begin{array}{c}9.89 \\
(8.8 \%) \\
\end{array}$ & $48.42 * * *$ & $54.87 * * *$ \\
\hline All firms & $\begin{array}{c}3.00 \\
(18.4 \%)\end{array}$ & $\begin{array}{c}10.00 \\
(10.8 \%)\end{array}$ & $\begin{array}{c}10.00 \\
(7.1 \%)\end{array}$ & $\begin{array}{c}20.00 \\
(8.6 \%)\end{array}$ & $\begin{array}{c}30.00 \\
(8.2 \%)\end{array}$ & $\begin{array}{c}10.09 \\
(6.9 \%)\end{array}$ & $\begin{array}{c}9.93 \\
(10.6 \%)\end{array}$ & $459.19 * * *$ & $129.58 * * *$ \\
\hline
\end{tabular}

Notes: Panels A and B of this table present median senior and subordinate CDS bid-ask spreads, respectively. Daily data on 5-year euro-denominated CDS with modified-modified restructuring are used for empirical analysis. For each firm, the first entry is the median bid-ask spread in basis point (bps) and the second is the median bid-ask spread defined as $100 *($ ask-bid $) /($ ask + bid $) / 2$. Tests for equality of medians are conducted for the bid-ask spread in bps. * $* *, * * *$ indicate significance at the 10,5 and 1 percent levels, respectively. 
Table 6: Liquidity transmission between CDS and stock

\begin{tabular}{|c|c|c|c|c|c|c|c|}
\hline \multirow[t]{3}{*}{ Periods } & & \multirow{2}{*}{\multicolumn{2}{|c|}{$\begin{array}{c}\text { Stock bid-ask spreads } \\
\text { (STK) }\end{array}$}} & \multirow{2}{*}{\multicolumn{2}{|c|}{$\begin{array}{c}\text { CDS bid-ask spreads } \\
\text { (CDS) }\end{array}$}} & \multicolumn{2}{|c|}{ Granger causality } \\
\hline & & & & & & \multirow{2}{*}{$\begin{array}{c}\text { Chi2 } \\
\text { Stock } \rightarrow \text { CDS }\end{array}$} & \multirow{2}{*}{$\begin{array}{c}\text { Chi2 } \\
\text { CDS } \rightarrow \text { Stock }\end{array}$} \\
\hline & & Coef. & Std. Err. & Coef. & Std. Err. & & \\
\hline \multirow[t]{4}{*}{ Pre-crisis } & STK(-1) & $0.1016^{* *}$ & $(0.0433)$ & $15.1744 * * *$ & $(3.5305)$ & \multirow[t]{4}{*}{$23.687^{* * *}$} & \multirow[t]{4}{*}{$23.526^{* * *}$} \\
\hline & $\operatorname{STK}(-2)$ & 0.0127 & $(0.0301)$ & $14.7837 * * *$ & (3.6906) & & \\
\hline & CDS(-1) & $-0.0003^{* *}$ & $(0.0001)$ & $0.5483 * * *$ & $(0.0516)$ & & \\
\hline & $\mathrm{CDS}(-2)$ & -0.0001 & $(0.0001)$ & $0.4010 * * *$ & $(0.0510)$ & & \\
\hline \multirow[t]{5}{*}{ Pre-disclosure } & STK(-1) & -0.2606 & $(0.1898)$ & 1.1315 & $(0.1068)$ & \multirow[t]{5}{*}{2.016} & \multirow[t]{5}{*}{$21.656^{* * *}$} \\
\hline & $\operatorname{STK}(-2)$ & -0.2633 & $(0.1810)$ & 0.5967 & $(0.1183)$ & & \\
\hline & CDS(-1) & $-0.0146 * * *$ & $(0.0034)$ & $0.6553 * * *$ & $(0.0452)$ & & \\
\hline & $\operatorname{CDS}(-2)$ & $-0.0139 * * *$ & $(0.0035)$ & $0.3159 * * *$ & $(0.0282)$ & & \\
\hline & BEAR & $-0.0009 * * *$ & $(0.0002)$ & 0.0032 & $(0.0147)$ & & \\
\hline \multirow[t]{5}{*}{ Disclosure\#1 } & STK(-1) & $0.4312 * * *$ & $(0.0830)$ & 0.0905 & $(0.4625)$ & \multirow[t]{5}{*}{3.954} & \multirow[t]{5}{*}{$11.313 * * *$} \\
\hline & STK $(-2)$ & $0.5419 * * *$ & $(0.0890)$ & $0.9275^{*}$ & $(0.5524)$ & & \\
\hline & CDS(-1) & $0.0329 * * *$ & $(0.0108)$ & $0.5418 * * *$ & $(0.0757)$ & & \\
\hline & $\operatorname{CDS}(-2)$ & $0.0252 * *$ & $(0.0102)$ & $0.2415^{* * *}$ & $(0.0836)$ & & \\
\hline & LEHM & 0.0002 & $(0.0006)$ & 0.0080 & $(0.0064)$ & & \\
\hline \multirow[t]{6}{*}{ Ban } & STK $(-1)$ & -0.0029 & $(0.0259)$ & -0.0574 & $(0.0625)$ & \multirow[t]{6}{*}{0.844} & \multirow[t]{6}{*}{0.026} \\
\hline & CDS(-1) & -0.0321 & $(0.1976)$ & $0.4510 * *$ & $(0.2210)$ & & \\
\hline & PSF & -0.1179 & $(0.1103)$ & -0.1749 & $(0.1248)$ & & \\
\hline & TAKE & 0.0026 & $(0.0098)$ & 0.0270 & $(0.0111)$ & & \\
\hline & LEHM & -0.0214 & $(0.0196)$ & -0.0181 & $(0.0285)$ & & \\
\hline & TARP & -0.0296 & $(0.0239)$ & -0.0241 & $(0.0252)$ & & \\
\hline
\end{tabular}


Table 6: Liquidity transmission between CDS and stock (continued)

\begin{tabular}{|c|c|c|c|c|c|c|c|}
\hline \multirow[t]{3}{*}{ Periods } & & Stock bid-a & spreads & CDS bid-a & spreads & \multicolumn{2}{|c|}{ Granger causality } \\
\hline & & \multicolumn{2}{|c|}{ (STK) } & \multicolumn{2}{|c|}{ (CDS) } & \multirow{2}{*}{$\begin{array}{c}\text { Chi2 } \\
\text { Stock } \rightarrow \text { CDS }\end{array}$} & \multirow{2}{*}{$\begin{array}{c}\text { Chi2 } \\
\text { CDS } \rightarrow \text { Stock }\end{array}$} \\
\hline & & Coef. & Std. Err. & Coef. & Std. Err. & & \\
\hline \multirow[t]{4}{*}{ Disclosure\#2 } & $\operatorname{STK}(-1)$ & $0.3156^{* * *}$ & $(0.0609)$ & $0.6138^{* *}$ & $(0.2897)$ & \multirow[t]{4}{*}{$4.489 * *$} & \multirow[t]{4}{*}{$58.050 * * *$} \\
\hline & $\operatorname{CDS}(-1)$ & $0.0709 * * *$ & $(0.0093)$ & $0.8672 * * *$ & $(0.0499)$ & & \\
\hline & PSF & (omitted) & & (omitted) & & & \\
\hline & APS & $0.0007^{*}$ & $(0.0004)$ & -0.0005 & $(0.0015)$ & & \\
\hline \multirow[t]{6}{*}{ Post-disclosure } & $\operatorname{STK}(-1)$ & $0.1466^{* * *}$ & $(0.0305)$ & 0.3124 & $(0.3463)$ & \multirow[t]{6}{*}{1.296} & \multirow[t]{6}{*}{$35.040 * * *$} \\
\hline & $\operatorname{STK}(-2)$ & $0.1455 * * *$ & $(0.0028)$ & -0.1897 & $(0.2924)$ & & \\
\hline & $\operatorname{CDS}(-1)$ & $0.0056^{* * *}$ & $(0.0015)$ & $0.5808 * * *$ & $(0.0457)$ & & \\
\hline & $\operatorname{CDS}(-2)$ & $0.0053 * * *$ & $(0.0015)$ & $0.3201 * * *$ & $(0.0381)$ & & \\
\hline & PSF & (omitted) & & (omitted) & & & \\
\hline & APS & $0.0008 * * *$ & $(0.0003)$ & -0.0005 & $(0.0017)$ & & \\
\hline \multirow[t]{10}{*}{ Whole sample } & $\operatorname{STK}(-1)$ & 0.0676 & $(0.0599)$ & 0.0243 & $(0.0243)$ & \multirow[t]{10}{*}{0.292} & \multirow[t]{10}{*}{$6.259 * *$} \\
\hline & $\operatorname{STK}(-2)$ & 0.0515 & $(0.0455)$ & 0.0076 & $(0.0498)$ & & \\
\hline & $\operatorname{CDS}(-1)$ & $0.0263 * *$ & $(0.0110)$ & $0.5103 * * *$ & $(0.0508)$ & & \\
\hline & $\operatorname{CDS}(-2)$ & $0.0277 * *$ & $(0.0112)$ & $0.3469 * * *$ & $(0.0499)$ & & \\
\hline & BEAR & $0.0087 *$ & $(0.0044)$ & -0.0101 & $(0.0090)$ & & \\
\hline & LEHM & $0.0181 * * *$ & $(0.0061)$ & -0.0141 & $(0.0152)$ & & \\
\hline & TARP & $0.0206^{* * *}$ & $(0.0073)$ & -0.0170 & $(0.0151)$ & & \\
\hline & PSF & $0.0756^{* *}$ & $(0.0312)$ & $-0.1098 *$ & $(0.0656)$ & & \\
\hline & TAKE & 0.0003 & $(0.0018)$ & $0.0091 * *$ & $(0.0042)$ & & \\
\hline & APS & $0.0016 * * *$ & $(0.0005)$ & 0.0016 & $(0.0015)$ & & \\
\hline
\end{tabular}

Notes: The table reports Granger Causality tests based on a panel autoregressive (pVAR) model with robust standard errors and lag selection by the modified AIC. The results of pVAR are based on daily data on 5-year euro-denominated senior CDS with modified-modified restructuring. The bid-ask spread is defined as $100^{*}($ askbid) $/($ ask+bid) $/ 2$. The Helmert transformation is used to remove panel-specific fixed effects. For the major US events including the Bear Stern collapse (BEAR), the Lehman Brothers collapse (LEHM), and the announcement of Troubled Asset Relief Program (TARP), dummy variable for each event equals one during the 5 business days following the event day. The government's public sector finance (PSF) is a dummy variable that equals one from $13 / 10 / 08$, the date of the announcement of the scheme, to the end of the sample for Lloyds and RBS and the date of acquisition for HBOS. The announcement of takeovers (TAKE) is a dummy variable that takes the value of one for the targets from the date of the announcement to the delisting: from 14/7/08 for Alliance and Leicester and from 13/10/08 for HBOS. The asset protection scheme (APS) is a dummy variable that takes the value of one for RBS from March to the end of the sample, and one for Lloyds from March to 3/11/09 when Lloyds exited the scheme. $* * *, * * *$ indicate significance at the 10,5 and 1 percent levels, respectively. 
Table 7: Probability of default

\begin{tabular}{|c|c|c|c|c|c|c|c|c|c|}
\hline \multirow[t]{2}{*}{ Firm } & \multicolumn{7}{|c|}{ Period } & \multicolumn{2}{|c|}{ Tests for equality of medians } \\
\hline & Pre-crisis & Pre-disclosure & Disclosure\#1 & Ban & Disclosure\#2 & Post-disclosure & Whole sample & $\begin{array}{c}\text { Disclosure\#1 \& } \\
\text { Ban } \\
\mathrm{Chi}^{2}(1) \\
\end{array}$ & $\begin{array}{c}\text { Ban \& } \\
\text { Disclosure\#2 } \\
\text { Chi }^{2}(1)\end{array}$ \\
\hline Alliance \& Leicester & 0.21 & 2.51 & 1.65 & NA & NA & NA & 0.33 & NA & NA \\
\hline Aviva & 0.15 & 0.81 & 1.79 & 3.00 & 5.36 & 1.55 & 1.43 & $91.70 * * *$ & $28.85 * * *$ \\
\hline Barclays & 0.09 & 0.92 & 1.90 & 2.12 & 3.25 & 1.49 & 1.30 & $6.70 * * *$ & $82.96 * * *$ \\
\hline Bradford \& Bingley & 0.26 & 2.82 & 6.50 & NA & NA & NA & 0.41 & NA & NA \\
\hline HBOS & 0.09 & 1.16 & 2.73 & 1.70 & NA & NA & 0.70 & $65.64 * * *$ & NA \\
\hline HSBC Holdings & 0.11 & 0.80 & 1.04 & 1.55 & 2.97 & 1.25 & 1.02 & $67.99 * * *$ & $141.87 * * *$ \\
\hline Legal \& General Group & 0.15 & 0.68 & 1.15 & 3.77 & 9.57 & 2.43 & 1.65 & $97.57 * * *$ & $43.78 * * *$ \\
\hline Lloyds TSB Group & 0.08 & 0.72 & 1.41 & 1.43 & 3.32 & 2.67 & 1.30 & 0.07 & $64.30 * * *$ \\
\hline Old Mutual & 0.29 & 0.95 & 1.93 & 8.00 & 17.09 & 3.63 & 1.98 & $111.82 * * *$ & $15.95 * * *$ \\
\hline Prudential & 0.09 & 0.96 & 1.87 & 1.92 & 4.79 & 3.24 & 1.77 & 0.86 & $66.82 * * *$ \\
\hline Royal Bank of Scotland & 0.19 & 0.88 & 1.21 & 2.03 & 1.94 & 0.93 & 0.90 & $85.44 * * *$ & 1.36 \\
\hline RSA Insurance Group & 0.13 & 0.92 & 1.36 & 2.65 & 4.32 & 1.27 & 1.16 & $98.19 * * *$ & $120.49 * * *$ \\
\hline Standard Chartered & 0.15 & 0.71 & 1.29 & 3.93 & 5.96 & 1.40 & 1.00 & $111.82 * * *$ & $28.85^{* * *}$ \\
\hline All firms & 0.14 & 0.95 & 1.70 & 2.40 & 4.18 & 1.89 & 1.15 & $179.68 * * *$ & $236.26^{* * *}$ \\
\hline
\end{tabular}

Notes: This table presents the probability of default for CDS firms. Daily data on 5-year euro-denominated CDS mid prices with modified-modified restructuring are used for

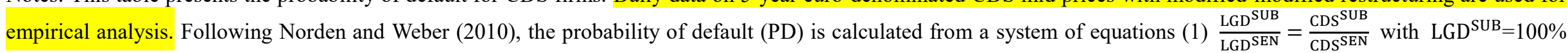
and (2) $\mathrm{PD}=\frac{\mathrm{CDS}^{\mathrm{SUB}}-\mathrm{CDS}^{\mathrm{SEN}}}{\mathrm{LGD}^{\mathrm{SUB}}-\mathrm{LGD}^{\mathrm{SEN}}}$ where $\mathrm{LGD}^{\mathrm{SUB}}$ is the market-implied loss given default of subordinate CDS, LGD ${ }^{\mathrm{SEN}}$ is the market-implied loss given default of senior CDS, $\mathrm{CDS}^{\mathrm{SUB}}$ is the credit default swap premium of subordinate CDS, and $\mathrm{CDS}^{\mathrm{SEN}}$ is the credit default swap premium of senior CDS. *,**,*** indicate significance at the 10,5 and 1 percent level, respectively. 
Table 8: Response of stock liquidity to CDS credit risk

\begin{tabular}{|l|l|l|}
\hline \multicolumn{1}{|c|}{ Explanatory variables } & Model 1 & Model 2 \\
\hline Disclosure\#1 & $0.1301 * * *$ & $-0.2362^{* * *}$ \\
& $(0.0243)$ & $(0.0375)$ \\
\hline Ban & $0.7981^{* * *}$ & $0.5770^{* * *}$ \\
& $(0.0231)$ & $(0.0431)$ \\
\hline Disclosure\#2 & $0.5955^{* * *}$ & $0.7480 * * *$ \\
& $(0.0246)$ & $(0.0611)$ \\
\hline PD x Disclosure\#1 & & $0.6250^{* * *}$ \\
& & $(0.0492)$ \\
\hline PD x Ban & & $0.2200^{* * *}$ \\
& & $(0.0369)$ \\
\hline PD x Disclosure\#2 & & $-0.1057 * * *$ \\
& & $(0.0071)$ \\
\hline
\end{tabular}

Notes: This table present fixed effects panel regression results for the impact of CDS risk on stock liquidity. Daily data on 5-year euro-denominated CDS with modified-modified restructuring are used for empirical analysis. The latter is measured by bid-ask spread defined as $100 *($ ask-bid)/(ask+bid)/2. Disclosure\#1 is a dummy variable that equals one during the pre-ban period and zero otherwise. Ban is a dummy variable that equals one during the ban period and zero otherwise. Disclosure\#2 is a dummy variable that equals one during the post-ban period and zero otherwise. PD is a probability of default calculated following Norden and Weber (2010). The standard errors are shown in the parentheses. *,**,*** indicate significance at the 10, 5 and 1 percent level, respectively. 
Table 9: Summary statistics of daily returns for CDS and non-CDS stocks

\begin{tabular}{|l|l|c|c|c|}
\hline \multicolumn{1}{|c|}{ Stocks } & Summary statistics & Disclosure\#1 & Ban & Disclosure\#2 \\
\hline \multirow{5}{*}{ CDS stocks } & Mean & $-0.42 \%$ & $-0.74 \%$ & $0.21 \%$ \\
\cline { 2 - 5 } & Median & $-0.58 \%$ & $-0.60 \%$ & $0.07 \%$ \\
\cline { 2 - 5 } & Standard deviation & $4.84 \%$ & $8.01 \%$ & $8.87 \%$ \\
\hline Non-CDS stocks & Mean & $-0.22 \%$ & $-0.24 \%$ & $0.13 \%$ \\
\cline { 2 - 5 } & Median & $-0.36 \%$ & $-0.51 \%$ & $0.15 \%$ \\
\cline { 2 - 5 } & Standard deviation & $3.56 \%$ & $5.95 \%$ & $3.96 \%$ \\
\hline
\end{tabular}

Notes: This table reports summary statistics of daily returns of CDS and non-CDS stocks in Disclosure\#1, Ban and Disclosure\#2 periods. The stock return is defined as the first log-difference of the closing prices. 
Table 10: Tests for equality of means and medians for CDS and non-CDS stocks

\begin{tabular}{|c|c|c|c|c|c|c|c|}
\hline \multirow[t]{2}{*}{ Stocks } & \multirow[t]{2}{*}{$\begin{array}{l}\text { Summary } \\
\text { statistics }\end{array}$} & \multirow[t]{2}{*}{ Disclosure\#1 } & \multirow[t]{2}{*}{ Ban } & \multirow[t]{2}{*}{ Disclosure\#2 } & \multicolumn{3}{|c|}{$\begin{array}{l}\text { Tests for equality } \\
\text { (t-stat for means, } \mathrm{Chi}^{2}(1) \text { for medians) }\end{array}$} \\
\hline & & & & & $\begin{array}{c}\text { Disclosure\#1 } \\
\& \\
\text { Ban } \\
\end{array}$ & $\begin{array}{c}\text { Ban } \\
\& \\
\text { Disclosure\#2 }\end{array}$ & $\begin{array}{c}\text { Disclosure\#1 } \\
\& \\
\text { Disclosure\#2 }\end{array}$ \\
\hline CDS & Mean & 0.15 & -13.18 & 4.48 & $-12.74 * * *$ & $11.95 * * *$ & $2.92 * * *$ \\
\hline Stocks & Median & 0.04 & -13.27 & 6.14 & $-90.72 * * *$ & $66.82 * * *$ & $7.70 * * *$ \\
\hline Non-CDS & Mean & -0.86 & 8.98 & 6.94 & $15.18 * * *$ & $-3.35 * * *$ & $14.04 * * *$ \\
\hline Stocks & Median & -1.04 & 9.45 & 8.11 & $78.43 * * *$ & 1.36 & $66.20 * * *$ \\
\hline
\end{tabular}

Notes: This table presents equality of mean (median) tests for CARs on CDS and non-CDS stocks between different pairs of periods (e.g., between Disclosure\#1 period and the Ban period). The stock return is defined as the first log-difference of the closing prices. Cumulative abnormal returns are defined as the difference between individual stock returns and the FTSE250 index return. *, **,*** indicate significance at the 10, 5 and 1 percent level, respectively. 
Figure 1: Median cumulative abnormal returns for CDS and other stocks
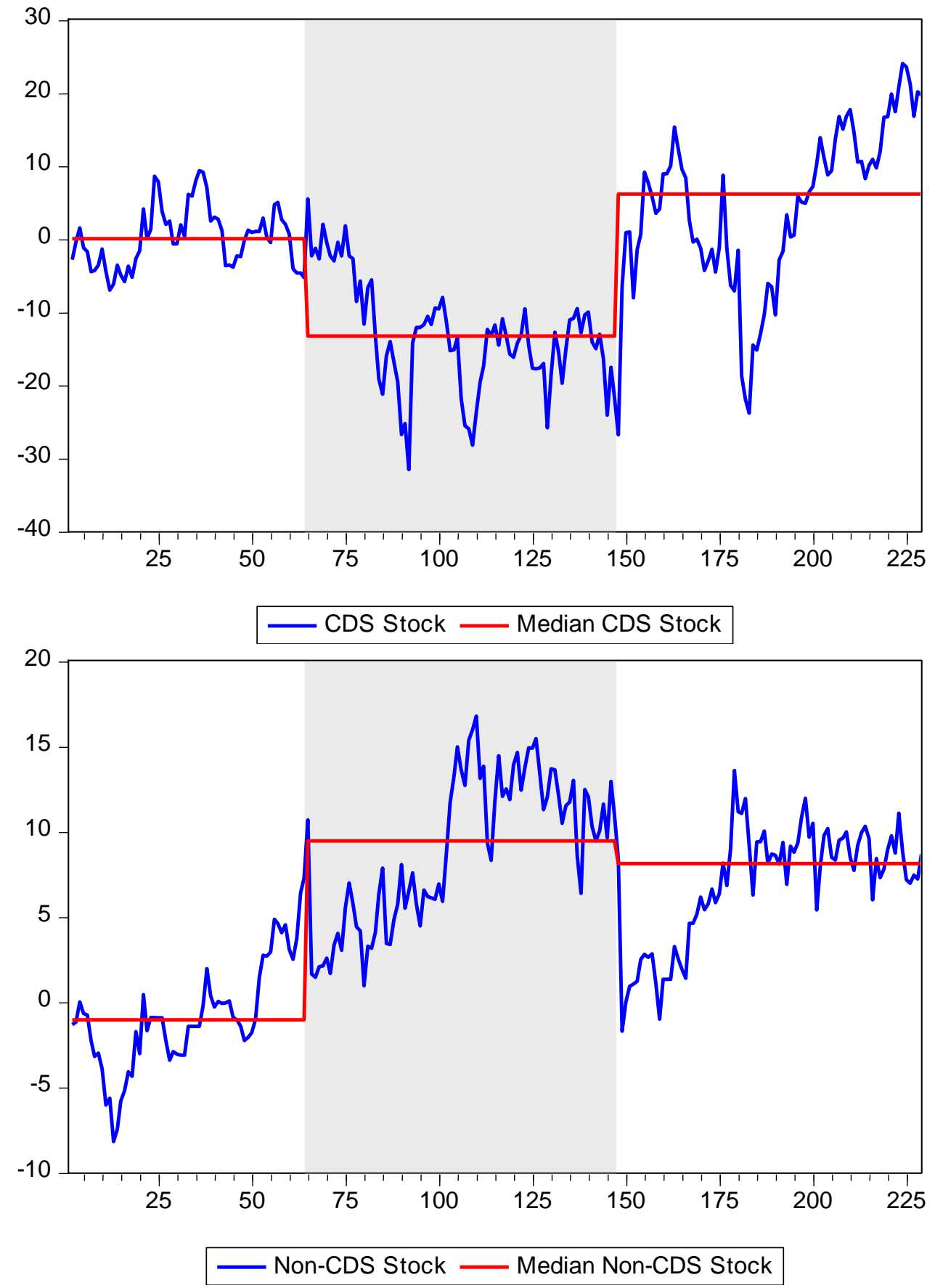

Notes: This figure plots the median cumulative abnormal returns (\%) for 13 CDS stocks and 20 non-CDS stocks from the beginning of the disclosure\#1 until the end of disclosure\#2 periods. The stock return is defined as the first log-difference of the closing prices. Cumulative abnormal returns are defined as the difference between individual stock returns and the FTSE250 index return. The beginning of disclosure\#1 corresponds to date 0 in the graphs. The short sales ban period is indicated by the shaded area. The unshaded areas before and after the ban period are disclosure\#1 and disclosure $\# 2$ periods, respectively. 